\title{
Belgium: Selected Issues Paper
}

This paper on Belgium was prepared by a staff team of the International Monetary Fund as background documentation for the periodic consultation with the member country. It is based on the information available at the time it was completed on February 24, 2012. The views expressed in this document are those of the staff team and do not necessarily reflect the views of the government of Belgium or the Executive Board of the IMF.

The policy of publication of staff reports and other documents by the IMF allows for the deletion of market-sensitive information.

\author{
Copies of this report are available to the public from \\ International Monetary Fund • Publication Services \\ $70019^{\text {th }}$ Street, N.W. • Washington, D.C. 20431 \\ Telephone: (202) 623-7430 • Telefax: (202) 623-7201 \\ E-mail: publications@imf.org Internet: http://www.imf.org
}

Price: $\$ 18.00$ a copy

\section{International Monetary Fund Washington, D.C.}




\section{INTERNATIONAL MONETARY FUND}

BELGIUM

\section{Selected Issues}

Prepared by Santiago Acosta-Ormaechea (FAD), Franziska Ohnsorge, and Sebastian Weber (both EUR)

Approved by the European Department

February 24, 2012

Contents

Page

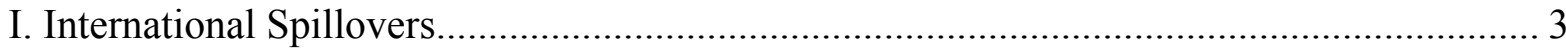

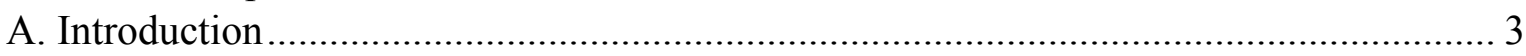

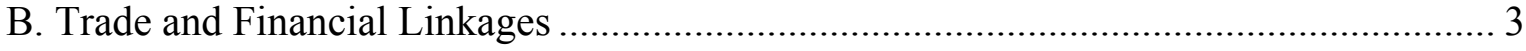

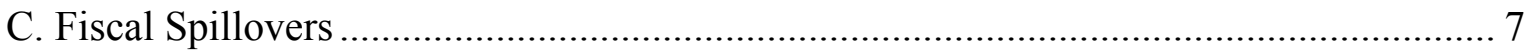

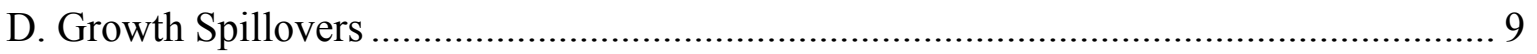

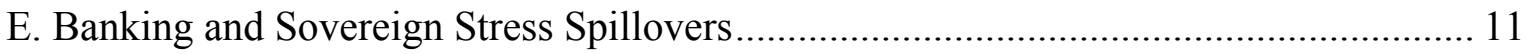

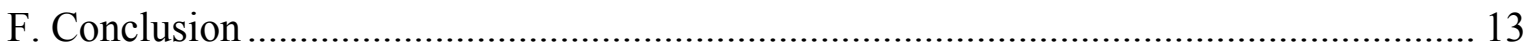

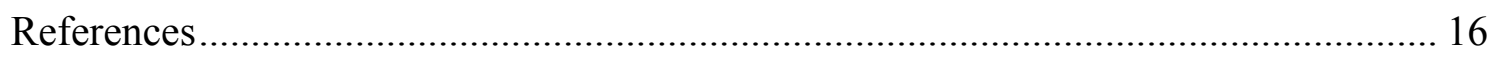

II. On A Revenue-Neutral Growth-Oriented Tax Reform For Belgium ............................ 17

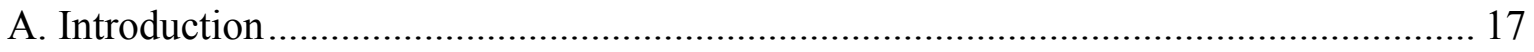

B. Overview of the Belgian Tax System .................................................................... 18

C. Labor and Business Taxation .................................................................................... 22

D. Brief Overview of Other Key Taxes in Belgium ................................................ 25

E. A possible Scenario for a Revenue-neutral Tax Reform in Belgium............................ 28

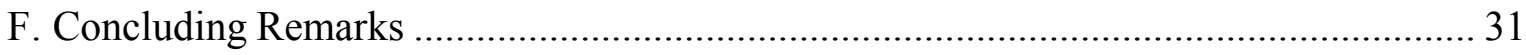

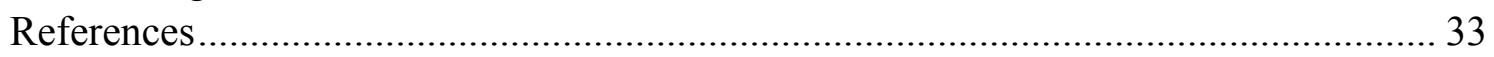

III. Towards Job-Creating Labor Market Reform.......................................................... 34

A. Characteristics of the Labor Market.......................................................................... 34

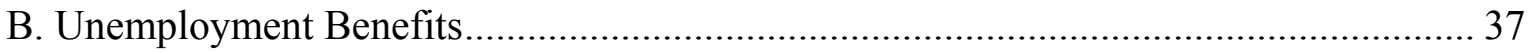

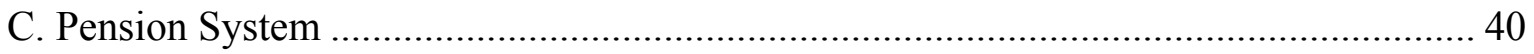

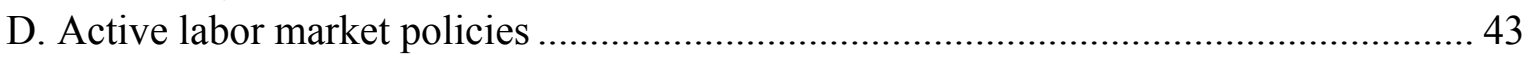

E. Impediments and Incentives for Mobility .......................................................... 44

F. The Importance of Labor Market Policies................................................................. 45

G. Further Reform Needs.................................................................................. 48

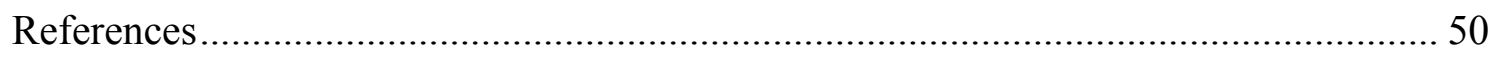




\section{Tables}

I.1 Trade by Regions and Countries, 2010 ................................................................

I.2 Belgian Bank Claims Abroad .................................................................................. 6

I.3 Belgian Bank Liabilities Abroad .............................................................................6

I.4. Foreign Direct Investment Positions .......................................................................6

II.1. Illustrative Quantification of Proposed Tax Measures................................................30

II.2. Illustration of Long-Run Effects of Proposed Measures on Key Macroeconomic

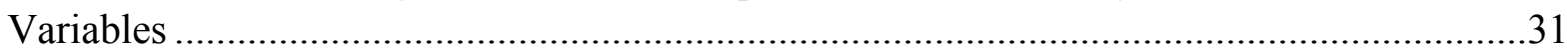

III.1. Panel OLS Regression. Dependent Variable: Employment Rate ................................47

\section{Figures}

I.1. Belgium: Consolidated Claims by Sector and Country ..............................................5

II.1. Selected Countries: Overall Tax Collection in 2009 ..................................................19

\section{Boxes}

I.1: A Measure of the Effect of Global Consolidation on Growth.........................................14

I.2: A Simulation Approach for the Downstream Risk from Defaults ................................15

II. 1. The Early 2000s Tax Reform ....................................................................................21

III.1. The Administration of Unemployment Benefits.................................................40

\section{Appendix Table}

A.1. Labor Market and Pension Reform Measures for 2012 …............................................52 


\section{INTERNATIONAL SPILLOVERS ${ }^{1}$}

\section{A. Introduction}

1. Belgium is a small open and highly integrated economy particularly susceptible to external shocks. This note sheds some light on potential spillovers to Belgium from various shocks originating in other countries. The note provides an overview of the extent of trade and financial openness of Belgium and the links to particular countries. Long-run and dynamic contributions from external sources to growth are quantified and used to forecast the potential loss to Belgian GDP from a growth slowdown in Europe in 2012. A more detailed analysis of potential sources of shocks and channels of transmission to growth is provided by assessing the potential impact of fiscal consolidation on Belgium's growth as well as the potential impact of banking sector losses on GDP from a sovereign default.

\section{B. Trade and Financial Linkages}

2. Belgium is highly dependent on trade with a limited number of countries. With an export to GDP ratio of 79 percent, Belgium belongs to the most open economies in Europe and also globally. Its exports are highly concentrated with a share of three quarters of total merchandise exports accounted for by the European Union (EU), close to two-thirds of which go to Germany, France, and the Netherlands. Developing countries and emerging markets account for a comparably small share of exports, despite recent export growth to Asia.

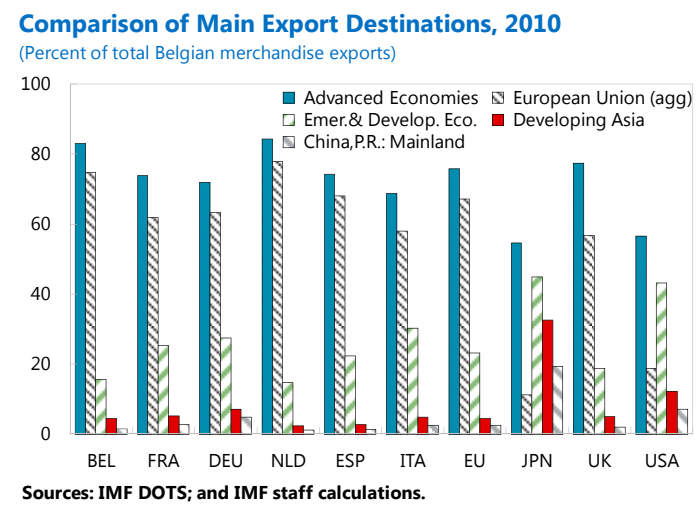
Imports are broadly in line with the export patterns.

\section{The international linkages of the} financial sector have declined since 2008 . As a consequence of the financial crisis and the split of Fortis along national borders, claims abroad dropped from the initial 320 percent of GDP peak in 2008:Q2 to less than a third. A further decline can be expected after the complete split of Dexia Group along national borders. As a consequence, Belgium's exposure has dropped from one of the highest in the euro

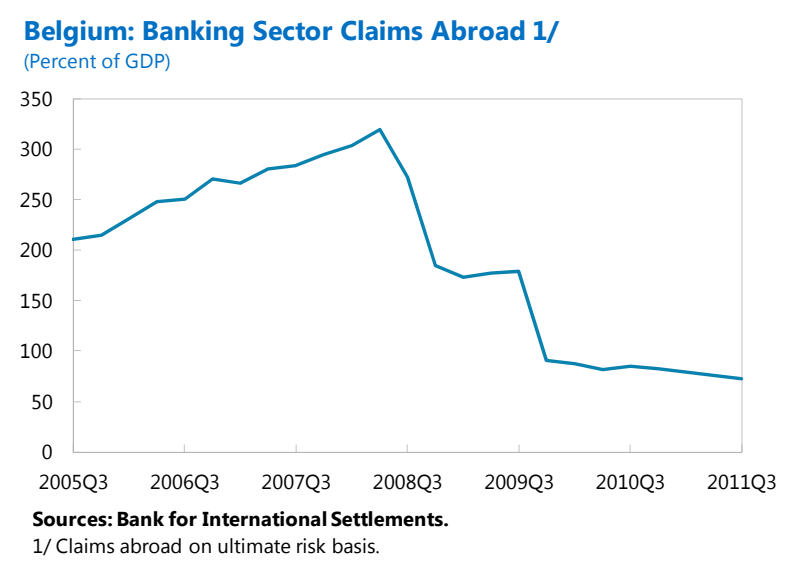

\footnotetext{
${ }^{1}$ Prepared by Sebastian Weber with input from Eugenio Cerutti (RES) on bank sector spillovers.
} 
area to an average level of roughly 73 percent of GDP, well below the current levels of France (110) and the Netherlands (164), but still above Portugal (52) or Italy (41).

Table I.1. Belgium: Trade by Regions and Countries, 2010

\begin{tabular}{|c|c|c|c|c|c|c|c|}
\hline \multirow[b]{2}{*}{ Origin/Destination } & \multirow{2}{*}{$\begin{array}{c}\text { Balance } \\
\text { Value in } \\
\text { millions of } \\
\text { U.S. dollars }\end{array}$} & \multicolumn{3}{|c|}{ Exports } & \multicolumn{3}{|c|}{ Imports } \\
\hline & & $\begin{array}{c}\text { Value in } \\
\text { millions of } \\
\text { U.S. dollars }\end{array}$ & $\begin{array}{c}\text { Share } \\
(\%)\end{array}$ & $\begin{array}{c}\text { Change } \\
(\%)\end{array}$ & $\begin{array}{c}\text { Value in } \\
\text { millions of } \\
\text { U.S. dollars }\end{array}$ & $\begin{array}{c}\text { Share } \\
(\%)\end{array}$ & $\begin{array}{c}\text { Change } \\
(\%)\end{array}$ \\
\hline Total & 15,059 & 402,833 & 100.0 & 9 & 387,775 & 100.0 & 10 \\
\hline EU & 28,055 & 301,577 & 74.9 & 7 & 273,522 & 70.5 & 9 \\
\hline Germany & 13,314 & 76,842 & 19.1 & 6 & 63,528 & 16.4 & 5 \\
\hline Netherlands & $-24,906$ & 49,095 & 12.2 & 12 & 74,002 & 19.1 & 17 \\
\hline France & 24,547 & 68,552 & 17.0 & 5 & 44,005 & 11.3 & 7 \\
\hline United Kingdom & 7,891 & 28,869 & 7.2 & 8 & 20,978 & 5.4 & 18 \\
\hline Italy & 6,891 & 18,933 & 4.7 & 7 & 12,042 & 3.1 & 3 \\
\hline Spain & 4,065 & 12,326 & 3.1 & 2 & 8,261 & 2.1 & 14 \\
\hline Poland & 2,870 & 6,658 & 1.7 & 16 & 3,789 & 1.0 & 10 \\
\hline Sweden & $-1,520$ & 5,839 & 1.4 & 17 & 7,359 & 1.9 & 26 \\
\hline America & $-2,689$ & 29,711 & 7.4 & 8 & 32,400 & 8.4 & 6 \\
\hline United States & 544 & 21,278 & 5.3 & 7 & 20,734 & 5.3 & 3 \\
\hline Developing Asia & $-7,590$ & 18,497 & 4.6 & 20 & 26,087 & 6.7 & 10 \\
\hline China,P.R.: Mainland & $-9,446$ & 6,288 & 1.6 & 4 & 15,734 & 4.1 & 9 \\
\hline Mid.East \& N. Africa & -47 & 9,810 & 2.4 & -1 & 9,857 & 2.5 & 39 \\
\hline
\end{tabular}

Source: IMF Direction of Trade Statistics.

4. However, exposures to selected countries remain significant. Notably claims on the U.K., the U.S., France, and the Czech Republic amount to between 6 and 13 percent of GDP. Belgium has one of the highest exposures to the three European IMF-program countries, with claims amounting to more than 51/2 percent of GDP (Figure 1), although mainly on non banks in Ireland (43/4 percent of GDP). The banking sector holds debt of high spread countries in the euro area exceeding 14 percent of Belgian GDP. ${ }^{2}$ Non-performing loans of foreign subsidiaries have risen in some markets and write-downs have increased, putting pressure on Belgian banks to deleverage. Based on a territorial principle, banks active in Belgium provide more liquidity to banks abroad than they receive. This is due to intragroup flows, for which claims by banks in Belgium largely exceed liabilities, reflecting the comfortable deposit base in Belgium and the large operations of Belgian banks' abroad, as for instance in Eastern Europe or Ireland. However, on a non intra-group basis, banks active in Belgium are net debtors to other countries. ${ }^{3}$ This is also reflected in the consolidated net position based on the ultimate risk basis, which indicates that Belgian banks (as opposed to banks active in Belgium) are net debtors to foreign countries. ${ }^{4}$ The sector's total foreign

\footnotetext{
${ }^{2}$ High spread countries include all countries with spreads above $200 \mathrm{bs}$ to the 10 -year German Bund as of $2011 \mathrm{Q} 1$.

${ }^{3}$ See also NBB, Financial Stability Review 2011, pages 41-42.

${ }^{4}$ However, the possibility that foreign liabilities include some liabilities of foreign banks' subsidiaries in Belgium cannot be excluded, as data tend to be limited.
} 
liabilities (on ultimate risk basis) equal broadly GDP and are predominantly toward France (46 $\frac{1}{2}$ percent of total foreign liabilities), and the Netherlands ( $243 / 4$ percent). The high liabilities create upstream risk, as there are mismatches between debtor and creditor banks in Belgium and countries to which debts exceed claims and to which the contrary is the case. Upstream risk is measured by a country's potential rollover need through both direct crossborder lending by banks, and the domestic lending operations by foreign affiliates that are funded by their parent bank. ${ }^{5}$ Belgium belongs to the euro area countries with the highest upstream risk when measured against the domestic GDP.

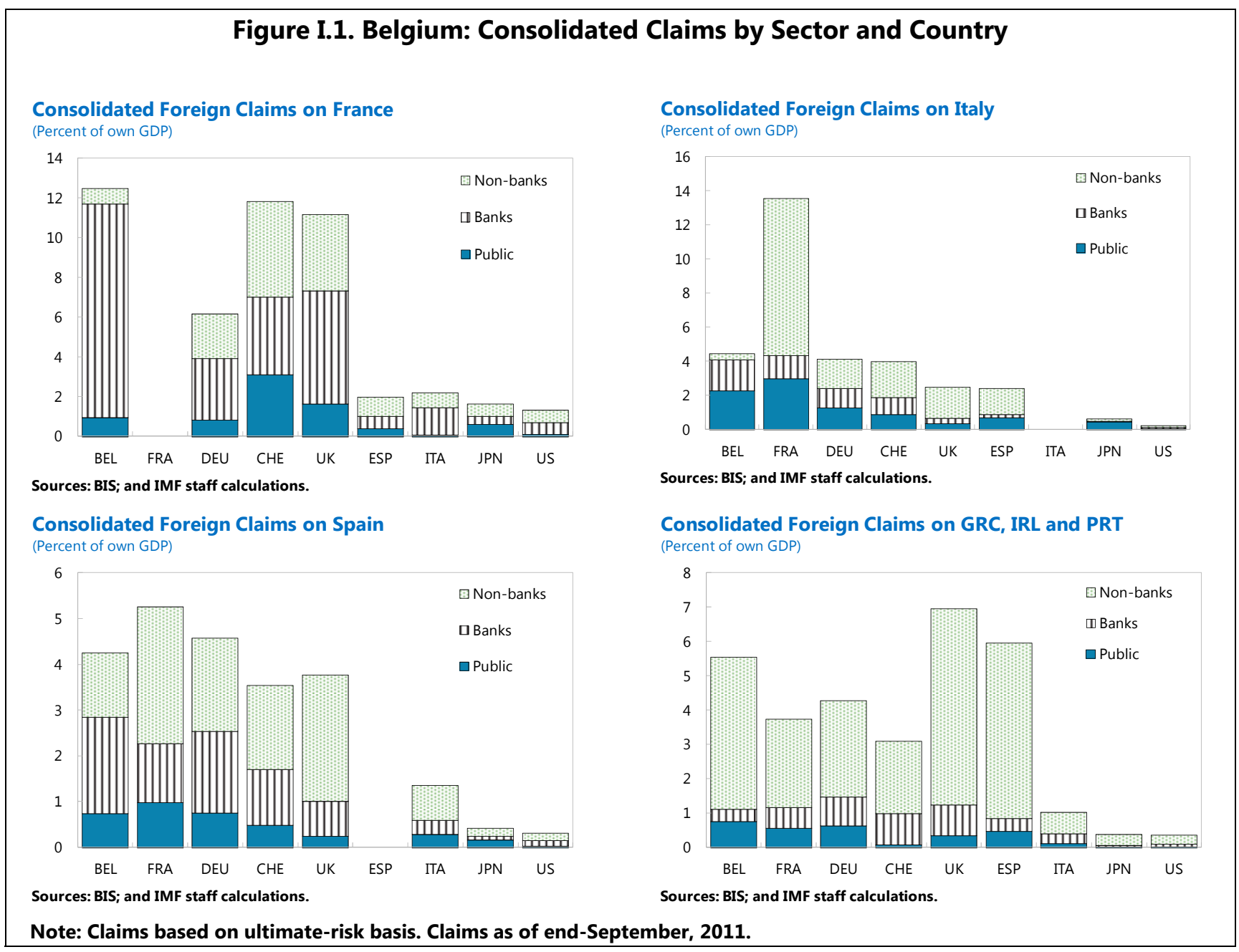

\footnotetext{
${ }^{5}$ In addition, the upstream exposure measure also includes the credit commitments (not used yet) that a borrower country has secured from BIS reporting banks.
} 
Table I.2. Belgian Bank Claims Abroad (As of end-Sep. 2011)

\begin{tabular}{cc}
\hline & Billions of \\
U.S. & \\
dollars & Share (percent) \\
\hline
\end{tabular}

All countries

Europe

France

Netherlands

Germany

United Kingdom

Switzerland

Austria

Sweden

GRC, IRL, ITA, ESP, PRT

Italy

Spain

Ireland

Greece

Portugal

Other developed countries

Japan

Australia

United States

Developing countries

Czech Republic

Hungary

Poland

Offshore centres

Source: BIS, on ultimate risk basis.
Table I.3 Belgian Bank Liabilities Abroad (As of end-Sep. 2011)

\begin{tabular}{rcc}
\hline $\begin{array}{c}\text { Billions of } \\
\text { U.S. dollars }\end{array}$ & $\begin{array}{c}\text { Share (\% of all } \\
\text { claims on Belgian } \\
\text { banks) }\end{array}$ & $\begin{array}{c}\text { Share (\% of } \\
\text { countries total } \\
\text { claims abroad) }\end{array}$ \\
\hline 494 & 100 & 2
\end{tabular}

04.2

17.2

6.4

4.5

10.5

0.4

0.7

0

19.7

6.1

5.9

6.4

0.4

0.9

8.5

0.2

0.5

7.6

25.9

13.4

4.1

4.4

1.3

Source: BIS, on ultimate risk basis.

\section{Foreign direct investment (FDI)} in Belgium is dominated by the neighboring countries, the U.K., and the U.S. France, Germany, the U.K., and the U.S. have higher investment position in Belgium compared to the investment position of Belgium in the respective country. France's FDI stock in Belgium (158 billion EUR) is larger than the combined FDI stock of the Netherlands, Luxembourg, and Germany. Similarly, Belgium's FDI is concentrated in France (42.2 billion EUR, the Netherlands (72.8 billion EUR), and Luxembourg (76 billion EUR).
Table I.4. Foreign Direct Investment Positions (billions of euros) (2010, or latest available)

by Belgiuim in: in Belgium by: Net position

\begin{tabular}{lrrr}
\hline France & 42.2 & 158.0 & 115.9 \\
Netherlands & 72.8 & 70.2 & -2.6 \\
Sweden & 0.7 & 15.2 & 14.6 \\
Spain & 9.5 & 6.1 & -3.4 \\
Luxembourg & 76.0 & 36.3 & -39.7 \\
Germany & 6.5 & 30.9 & 24.4 \\
Ireland & 4.4 & 6.6 & 2.1 \\
United Kingdom & 13.0 & 47.9 & 35.0 \\
Italy & 11.2 & 13.6 & 2.5 \\
Poland & 3.5 & 0.0 & -3.5 \\
Czech Republic & 3.6 & 0.0 & -3.6 \\
Switzerland & 3.7 & 8.4 & 4.7 \\
Hungary & 3.8 & 0.0 & -3.8 \\
Finland & 0.4 & 22.3 & 21.8 \\
United States & 12.6 & 48.4 & 35.8 \\
Japan & 0.3 & 10.0 & 9.7 \\
\hline
\end{tabular}

Source: Eurostat, as reported by source country 
6. Belgium has a relatively high share of migrants which are predominantly from the EU. The share of non-citizens registered in Belgium account for close to 10 percent of the total population. Compared to other European countries, Begium has one of the lowest non-EU migrant population relative to the total migrants. The high share of total migrants and the bias toward EU citizens is partly explained by the presence of several EU institutions in Belgium.

\section{Belgium's international linkages are,} thus, dominated by France, the Netherlands, Germany and the U.S. The most important trade and financial ties are with France, followed by Germany, the Netherlands and the U.S. Trade and financial linkages to Belgium appear equally important for France and Netherlands, respectively. Ties to Germany are biased toward trade linkages, while ties with the U.S. are more reliant on FDI and banking sector linkages. Other countries are relevant for particular linkages, such as Luxembourg for FDI and the Czech Republic for banking sector linkages. Linkages with Greece and Portugal are very limited, but financial linkages to Ireland, Italy, and Spain are substantial, jointly exceeding those to Germany or the Netherlands. Migrants are largely from the EU-27, reflecting Belgium's particular role in the EU institutional landscape.

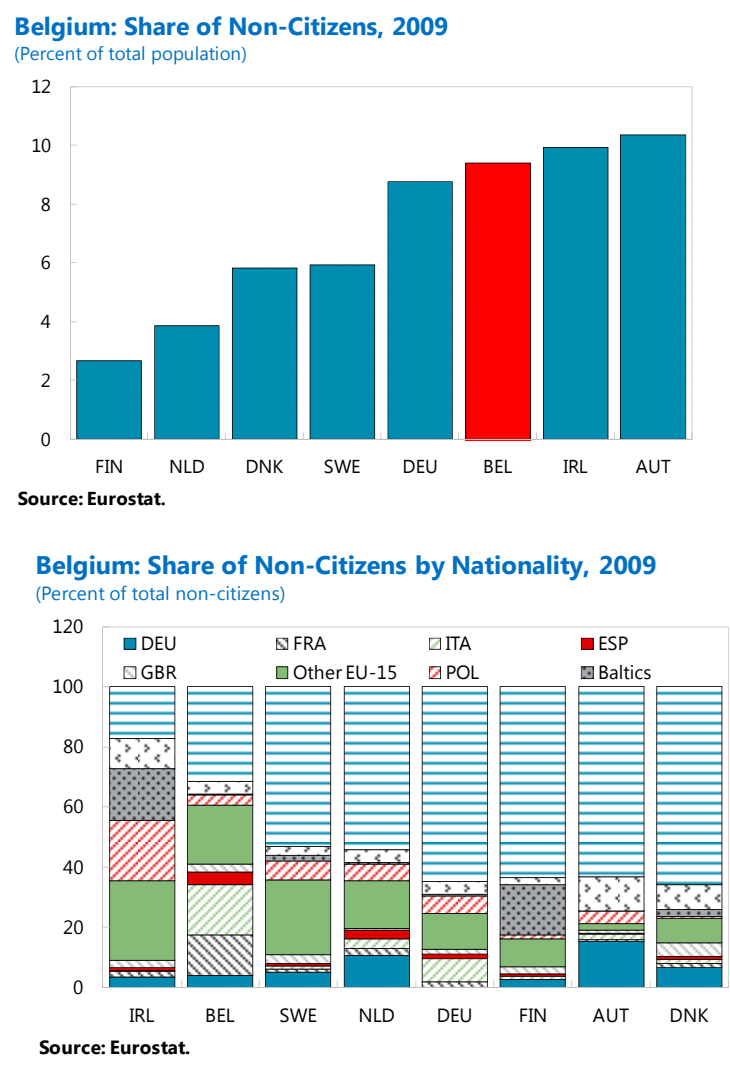

\section{Fiscal Spillovers}

\section{The concentration of exports makes Belgium particular sensitive to the} envisaged fiscal consolidation efforts in trading partners. With more than three quarters of exports destined to the EU, Belgian exports are vulnerable to faltering demand in European countries. Belgian's main trading partners-France, the Netherlands, and Germany - are projected to tighten their structural fiscal balances by 1 percent of the respective countries GDP in 2012 and 1/2 percent in 2013. This could imply a marked reduction of demand for Belgian exports which potentially translates into non-negligible effects on overall GDP growth. 


\section{GDP growth could slow notably due to projected fiscal consolidation. We}

simulate for 2011-13 the effect of Belgian and global fiscal consolidation on Belgium's output growth, allowing for carry-over effects from fiscal changes in the previous period to current GDP growth, using a model based on the national accounting framework. ${ }^{6}$ Estimates are based on the cyclically adjusted revenue and expenditure changes of 20 countries which cover about 70 percent of world GDP and more than 80 percent of Belgian exports. We find that overall growth could be lower by about $1 / 2$ percentage points in 2011 and 2012 and

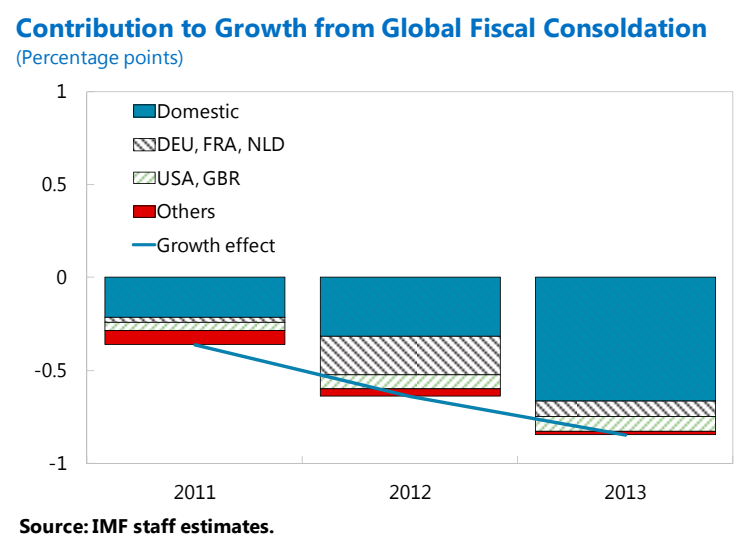
$3 / 4$ percentage points in 2013 , due to fiscal consolidation. The simulation results indicate that the domestic effect of fiscal consolidation in Belgium reduces output by $1 / 4$ percentage points in 2011, driven largely by carry-over effects from the consolidation in 2010. The impact of domestic consolidation on growth will be felt in 2013 due to the significant planned consolidation efforts in 2012 and 2013.

\begin{tabular}{|c|c|c|c|c|c|c|c|c|c|}
\hline & \multicolumn{9}{|c|}{$\begin{array}{c}\text { Fiscal Contribution to Growth } \\
\text { (In percentage points) }\end{array}$} \\
\hline & \multicolumn{3}{|c|}{2011} & \multicolumn{3}{|c|}{2012} & \multicolumn{3}{|c|}{2013} \\
\hline & \multirow{2}{*}{$\begin{array}{l}\text { Total } \\
\text { growth } \\
\text { impact }\end{array}$} & \multicolumn{2}{|c|}{ Of which: } & \multirow{2}{*}{$\begin{array}{l}\text { Total } \\
\text { growth } \\
\text { impact }\end{array}$} & \multicolumn{2}{|c|}{ Of which: } & \multirow{2}{*}{$\begin{array}{l}\text { Total } \\
\text { growth } \\
\text { impact }\end{array}$} & \multicolumn{2}{|c|}{ Of which: } \\
\hline & & $\begin{array}{c}\text { domestic } \\
\text { effect }\end{array}$ & $\begin{array}{c}\text { spillover } \\
\text { effect }\end{array}$ & & $\begin{array}{c}\text { domestic } \\
\text { effect }\end{array}$ & $\begin{array}{c}\text { spillover } \\
\text { effect }\end{array}$ & & $\begin{array}{c}\text { domestic } \\
\text { effect }\end{array}$ & $\begin{array}{l}\text { spillover } \\
\text { effect }\end{array}$ \\
\hline $\begin{array}{l}\text { Belgium } \\
\text { of which: }\end{array}$ & -0.4 & -0.2 & -0.1 & -0.6 & -0.3 & -0.3 & -0.8 & -0.7 & -0.2 \\
\hline - current year & -0.2 & 0.1 & -0.2 & -0.5 & -0.4 & -0.1 & -0.5 & -0.4 & -0.1 \\
\hline - carry over prev. year & -0.2 & -0.3 & 0.1 & -0.2 & 0.1 & -0.2 & -0.4 & -0.3 & -0.1 \\
\hline PPP weighted average & -0.2 & -0.1 & 0.0 & -0.3 & -0.3 & -0.1 & -0.4 & -0.3 & -0.1 \\
\hline Simple average & -0.5 & -0.4 & -0.1 & -0.7 & -0.5 & -0.1 & -0.4 & -0.3 & -0.1 \\
\hline
\end{tabular}

Source: IMF staff estimates.

1/ Financial sector support recorded above-the-line was excluded for the calcualtion of growth impact for Ireland (2.5 percent of GDP in 2009 and 5.3 percent of GDP in 2010 )and the US (2.5 percent of GDP in 2009, 0.4 percent of GDP in 2010, and 0.1 percent of GDP in 2011 and 2012). Financial sector support is not expected to have a significant impact on demand. For Russia only non-oil revenues are assumed to have an impact on growth. Values need not add up due to rounding.

10. Negative growth spillovers from global fiscal consolidation are likely to be relatively high in $2012 / 13$. The negative growth effect from global fiscal consolidation could amount to about $1 / 4$ percentage point in both 2012 and 2013. More than 50 percent of the spillovers are from the three main trading partners. The U.S. and the U.K. account for another 25 percent and the remaining 25 percent are accounted for by the other countries in the sample. Belgium's trade openness and export exposure to countries with relatively high consolidation efforts imply that spillovers to Belgium are about twice the average spillovers in the sample of 20 countries.

\footnotetext{
${ }^{6}$ For a detailed description see Ivanova and Weber (2011).
} 


\section{Growth Spillovers}

\section{Belgian GDP growth co-moves strongly with GDP growth in its three main} trading partners. The strong co-movement is potentially due to Belgium being hit by similar common shocks as its main trading partners, the spillovers of domestic shocks from the main trading partners to Belgium, and the spillovers from Belgium to its main trading partners. Given its economic size and openness to trade, the latter is less likely. A simple regression of the Belgian quarter-on-quarter GDP growth rate on the (contemporaneous) quarter-on-quarter growth rates of the four largest euro zone members-France, Spain, Italy, and Germany-reveals that close to 50 percent of the variation in Belgian GDP growth can be explained by those four countries. The average fraction explained by the four countries for other euro zone members is about half that amount. Thus, Belgium reacts potentially more strongly to a growth slowdown in the euro zone.

\section{A multi-country VAR analysis is} used to assess the risk to GDP growth in Belgium from a decline in domestic demand in other high government bond spread countries. The assumption underlying the scenario is a $1 / 2$ standard deviation reduction in the growth rate of the domestic growth component of Italy, Spain, Greece, Ireland and Portugal for each quarter in 2012 compared to the implied growth rates under the Spring 2012 WEO projections. The decomposition and forecasts under this scenario are constructed using the VAR approach described in Poirson and Weber (2011), which allows decomposing the growth rate into a long-run, a dynamic domestic and a dynamic foreign component. After decomposing growth into the three components, the domestic components for the five countries are adjusted and the new growth rates
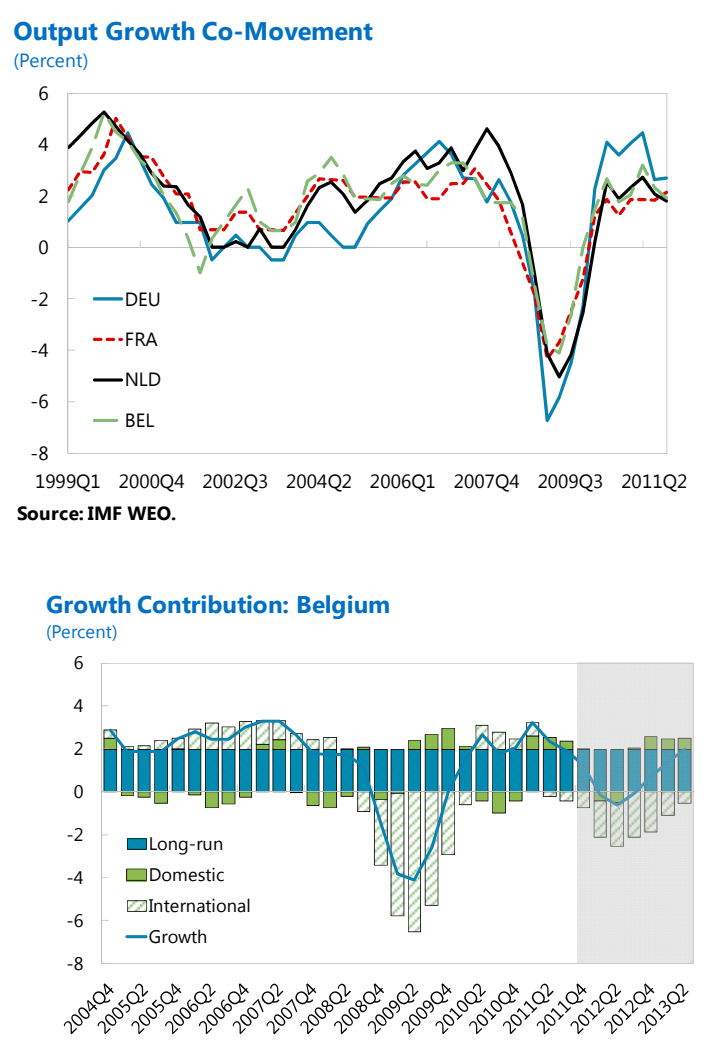

Sources: IMF WEO; OECD; and Poirson and Weber (2011).

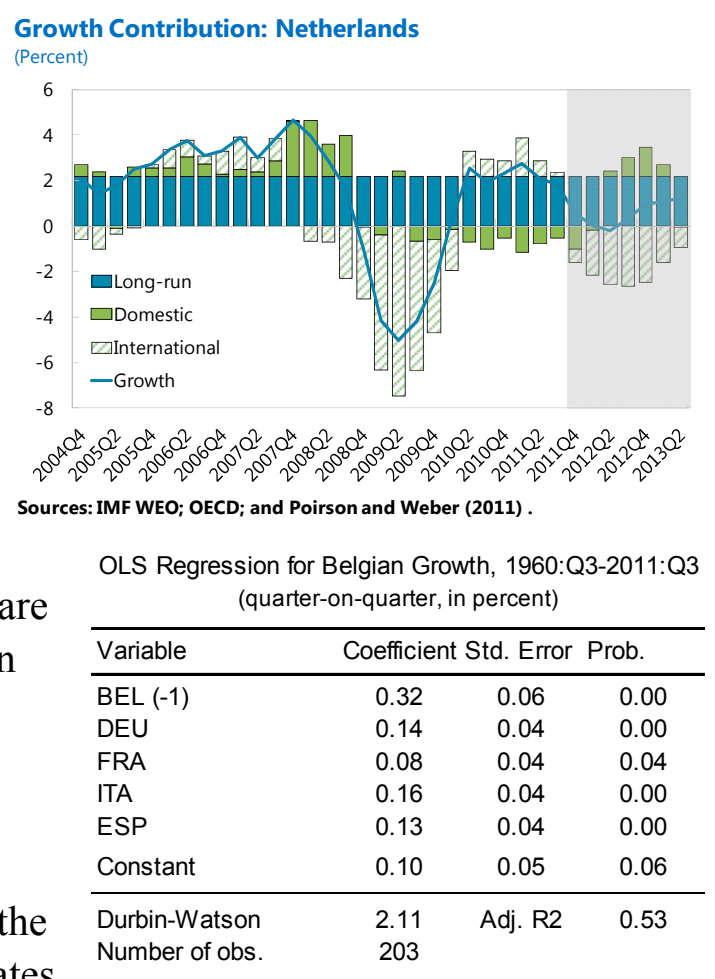


for all 17 countries in the sample are computed, holding all other domestic components unchanged (thus results underestimate the impact). The approach has the advantage that it takes third country effects - e.g. the impact of the fall in Italian domestic demand channeled via Germany on Belgium - into account and is thus estimating the impact consistently across the 17 countries in the sample.

\section{Belgian growth is largely explained by foreign shocks, reflecting the openness} and interconnectedness of the economy. Estimation results suggest that Belgium's GDP dynamics are largely dominated by spillovers from domestic shocks in other economies. Long-run growth is estimated at just below 2 percent. More than 70 percent of the long-run growth is accounted for by long-run growth in other economies. Similarly, close to 70 percent of the variance of the dynamic component is explained by the variation in the international component. Unlike in the Netherlands, for instance, the boom period prior to the crisis was largely accounted for by positive growth spillovers from abroad. The recent recovery was supported by increased external demand and was followed by a revival of domestic demand. Both are expected to drag down GDP in the coming quarters under the baseline WEO projections.

14. A shock to domestic demand in the high spread countries in 2012 could cause an output contraction in Belgium in 2012 and lower growth by about $1 / 2$ percentage points in 2013. The response is stronger than in France and Germany, but in line with the response in the Netherlands. The output reduction is caused primarily by lowered support from Italy and Spain to growth in Belgium, and would lower growth by $3 / 4$ percentage points in 2012 . The combined contribution of Portugal and Ireland is contained to below 0.2 percentage point in any quarter. There are no notable negative spillovers from the growth slowdown in Greece.

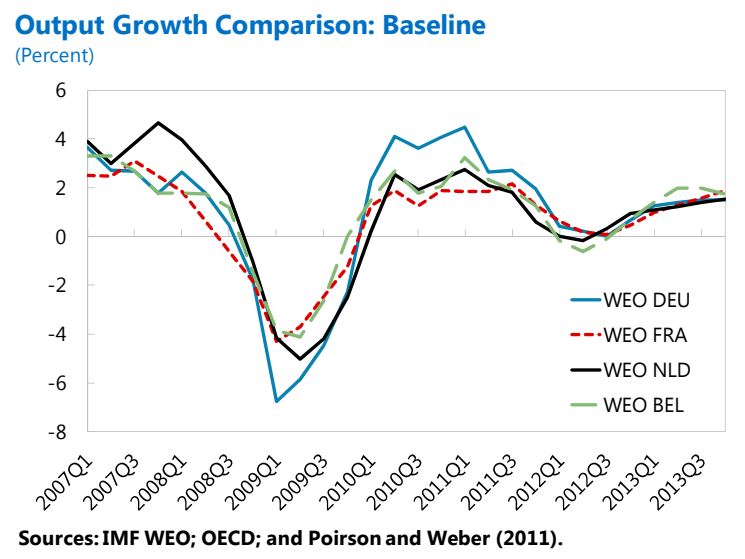

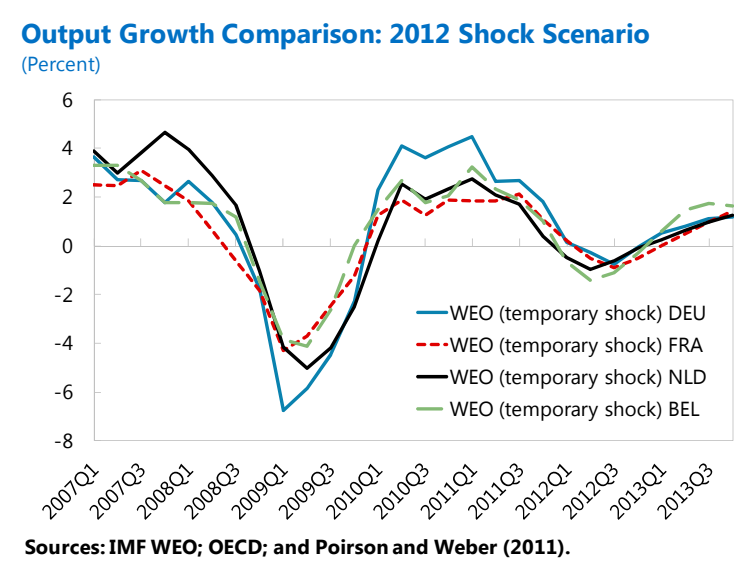

\footnotetext{
${ }^{7}$ The international component includes also three exogenous shocks: a dummy for the oil shock in 1979, a dummy for the oil shock in 1990, and a dummy for the recent financial crisis. The sample extends from 1975Q1 to 2011Q3. The country sample includes: Austria, Belgium, Canada, Finland, France, Germany, Greece, Ireland, Italy, Japan, the Netherlands, Portugal, Spain, Sweden, Switzerland, the United Kingdom and the United States
} 


\section{E. Banking and Sovereign Stress Spillovers}

15. The diminished foreign exposure of the aggregate banking sector since the onset of the financial crisis has reduced the potential loss from a default in other countries. Building on the RES/MFU Bank Contagion Module, a spillover analysis is conducted to simulate the direct effects of losses on Belgian bank claims abroad. ${ }^{8}$ A scenario of 50 percent losses on sovereign exposures to Greece implies a manageable direct loss to the aggregate banking sector of Belgium. Even a scenario in which Irish and Portuguese sovereign exposures would register similar loss rates would imply a relatively mild direct loss of $1 / 2$ percent of GDP for Belgian bank lenders. However, the analysis is performed at the aggregate level and thus hides potentially larger losses at individual bank levels. The latter may cause a knock on effect to other banks. Similarly, deleveraging needs are computed based on the tier 1 capital ratio of the aggregate banking sector and thus hide potential deleveraging needs of individual banks. Using individual bank data would potentially imply different deleveraging needs also at the aggregate level. Thus aggregate results should be interpreted with care.

Spillovers to Belgium from International Banks' Sovereign Exposures as of March 2011

\begin{tabular}{lrrrr}
\hline Shock Originating From & Magnitude 1/ & $\begin{array}{c}\text { Deleveraging } \\
\text { Need 2/ }\end{array}$ & $\begin{array}{c}\text { Belgian Lenders' } \\
\text { Losses (percent } \\
\text { GDP) }\end{array}$ & $\begin{array}{c}\text { Impact on Credit } \\
\text { Availability (percent } \\
\text { of GDP) 3/ }\end{array}$ \\
\hline Greece & 50 & 0.0 & 0.2 & -0.1 \\
Greece, Ireland, Portugal & 50 & 0.0 & 0.5 & -0.3 \\
\hline
\end{tabular}

Source: RES/MFU Bank Contagion Module based on BIS, ECB, and IFS data.

$1 /$ Magnitude denotes the percent of sovereign on-balance sheet claims that default.

2/ Deleveraging need is the amount (in percent of Tier I capital) that needs to be raised through asset sales in response to the shock in order to meet a domestic banking sector Tier I capital asset ratio of 8 percent, expressed in percent of total assets and assuming no recapitalizations.

$3 /$ Reduction in foreign banks credit on Belgium due to the impact of their shock in their balance sheet, assuming a uniform deleveraging across domestic and external claims.

16. Risks remain with respect to creditor banks' exposures to high spread countries and the associated potential impact on credit availability in Belgium due to lending by French and Dutch creditor banks. Exposures of Belgian foreign lenders to losses in Greece, Ireland and Portugal are primarily on the non-bank private sector. Extending the default scenario to include these sectors - but reducing the haircut to 30 percent —implies a more significant loss to Belgian foreign bank lenders which exceeds 2 percent of GDP. Potential losses to individual country shocks are the largest with respect to the U.S., the U.K., and France. A haircut of 10 percent on exposures to the U.S., the U.K., or France could generate a direct loss of between 1.2 to 2.2 percent of GDP to the Belgian bank lender. The required adjustment in affected banks and the associated impact on credit availability in Belgium is particularly high in the case of a default in the Netherlands and France, as these countries have significant cross-border exposures to Belgium. However, it should be noted that the direct effects in such a scenario are likely to be less relevant than the indirect effects

\footnotetext{
${ }^{8}$ See Cerutti et al (2011) and Tressel (2010) for methodological details.
} 
Spillovers to Belgium from International Banks' Exposures as of March 2011

\begin{tabular}{lccrr}
\hline Shock Originating From & Magnitude 1/ & $\begin{array}{c}\text { Deleveraging } \\
\text { Need 2/ }\end{array}$ & $\begin{array}{c}\text { Belgian Lenders' } \\
\text { Losses (percent } \\
\text { GDP) }\end{array}$ & $\begin{array}{c}\text { Impact on Credit } \\
\text { Availability (percent } \\
\text { of GDP) 3/ }\end{array}$ \\
\hline Greece & 30 & 0.0 & 0.1 & -0.1 \\
Greece, Ireland, Portugal & 30 & 0.0 & 2.1 & -1.3 \\
Italy & 10 & 0.0 & 0.6 & -0.9 \\
Spain & 10 & 0.0 & 0.5 & -0.9 \\
France & 10 & 0.0 & 1.7 & -13.6 \\
Germany & 10 & 0.0 & 0.8 & -8.0 \\
Netherlands & 10 & 0.0 & 0.9 & -25.7 \\
UK & 10 & 0.0 & 2.2 & -6.7 \\
European Countries 4/ & 10 & 100.0 & 9.2 & -95.7 \\
US & 10 & 0.0 & 1.2 & -3.9 \\
\hline
\end{tabular}

Source: RES/MFU Bank Contagion Module based on BIS, ECB, and IFS data.

$1 /$ Magnitude denotes the percent of on-balance sheet claims (all borrowing sectors) that default. 2/ Deleveraging need is the amount (in percent of Tier I capital) that needs to be raised through asset sales in response to the shock in order to meet a domestic banking sector Tier I capital asset ratio of 8 percent, expressed in percent of total assets and assuming no recapitalizations.

$3 /$ Reduction in foreign banks credit to Belgium due to the impact of the analyzed shock in their balance sheet, assuming a uniform deleveraging across domestic and external claims.

4/ Greece, Ireland, Portugal, Italy, Spain, France, Germany, Netherlands, and UK

\section{Estimates indicate potential weaknesses from specific exposures, but values} should be treated with care, as indirect channels, associated with a default in any country, are likely to be much larger. Although the simulations take into account second round deleveraging effects, the results abstract from the effects on confidence, asset prices, the implication of a potential default by a sovereign or bank for the functioning of the interbank market, and more importantly the banks' deleveraging would impact GDP, which could also translate into further bank losses through an increase in non-performing assets. These effects could potentially be much more damaging than the direct spillover effect. Additionally, off-balance sheet items are not taken into account, which implies a likely underestimation of the direct effect.

\section{The public support to the banking sector and the increased risk aversion of} investors to sovereign debt contributed to the sharp rise of Belgian government bond spreads. The high debt burden, the exposure of the banking sector to high spread countries, and the increase in contingent liabilities due to the government guarantees have contributed to the increased sensitivity of the Belgian government bond yields to foreign factors. A VAR analysis is used to assess the domestic factors and the contribution from various countries' spreads to the Belgian government bond spread, using a sample of 14 countries. ${ }^{9}$

\footnotetext{
${ }^{9}$ The approach is similar to Poirson and Weber (2011). The countries in the sample include: Austria, Belgium, Denmark, Finland, France, Greece, Ireland, Italy, Netherlands, Portugal, Spain, Sweden, Switzerland, and United Kingdom. Spreads over the German Bund are measured at weekly frequency. Results are based on the average estimates from 46 different Choleski identification schemes. Excluding the non-euro area countries leaves the main findings unaltered.
} 

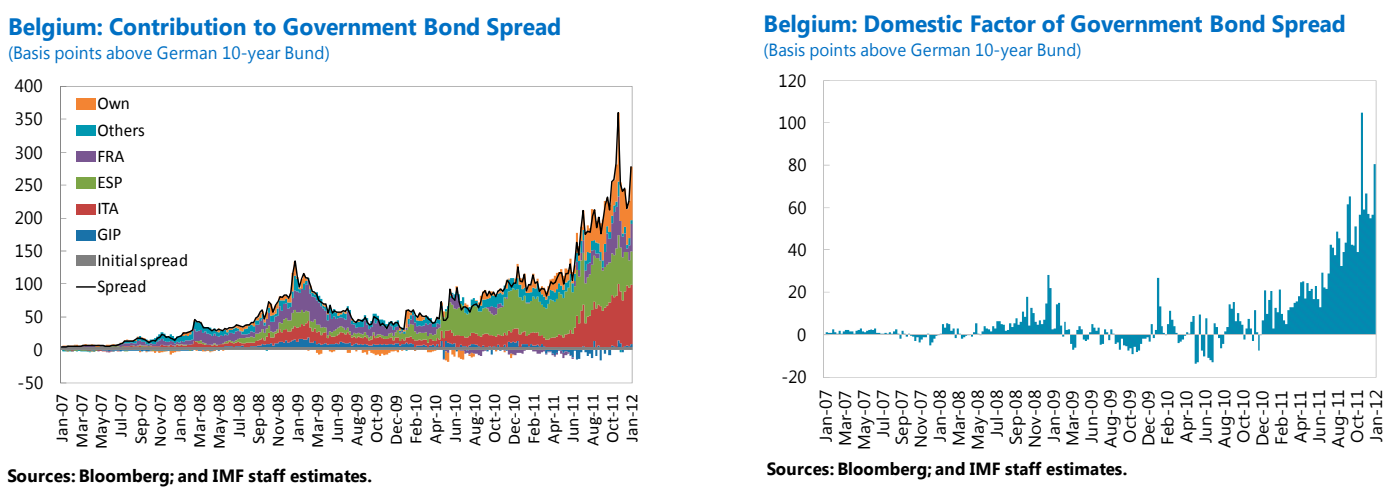

19. Most of the variation in the Belgian government bond spread appears to be associated with external factors. In early 2007, the increase in Belgian bond spreads was driven by the co-movement with the spreads of Portugal, Ireland and Greece.

Throughout 2008 and 2009, the increase in the spread was associated with an increase in the French and Italian spread. In May 2010, spreads jumped up due to the developments in Greece while the French contribution declined. Throughout 2010, first the contribution of Spain and then, in 2011, the contribution of Italy started rising. By end 2011, a co-movement with France can be detected as the spread over the Bund for Belgian bonds reached a record high.

\section{There are two distinct episodes in which domestic factors played a relevant role}

in the increase of the spread. In late 2008 and early 2009, domestic factors accounted for an average of 15 percent of the increase in the spread reflecting the concerns around the banking sector and the needed capital injections by the state, which was already under strain due to the elevated debt level. In late 2009 and 2010, the contribution of the domestic factors to the spread receded almost completely. However, as a result of the continued deadlock of the government creation in Belgian, contagion fears started pushing the spread further up by the end of 2010 and the renewed concerns around Dexia Group supported the high domestic contribution throughout 2011. The domestic contribution dropped from its 105 basis points peak to 60 basis points, when the new budget deal was announced clearing the way for the government formation at the end of November 2011.

\section{F. Conclusion}

21. Belgium remains a highly integrated economy sensitive to foreign shocks, although financial cross-border linkages have declined strongly since 2008. The problems in the Belgian banking sector have caused one of the strongest reductions in foreign exposures in the European banking sector landscape. Thus, less direct transmission of external shocks via financial channels can be expected in the future. The high degree of trade openness has helped Belgium recover quickly in 2010 through a strong contribution to growth from net trade. However, the flip-side of the trade openness and the trade-linkages with countries that have embarked on significant fiscal consolidation is that Belgium is particular susceptible to a growth slow-down in the region. Falling foreign demand is therefore likely to exert a notable drag on GDP in 2012-13. The strong co-movement with other countries' government spreads is another source of risk, as heightened interest rates and debt servicing costs hamper economic growth. 


\section{Box I.1. A Measure of the Effect of Global Consolidation on Growth}

The representation of the national accounts and behavioral assumptions for government spending, taxes, consumption, investment, exports and imports can be used to simulate the effect of global consolidation on growth. Starting point is the national accounting identity:

$$
Y_{t, j}=C_{t, j}+I_{t, j}+G_{t, j}+X_{t, j}-M_{t, j}
$$

where $Y_{t, j}$ is the real output, $I_{t, j}$ is real investment, $G_{t, j}$ is the real government spending, $X_{t, j}$ is are real exports and $M_{t, j}$ are real imports of country $j$ in time $t$ denominated in a common currency. The individual components of output are respectively given by:

$\begin{array}{lll}C_{t, j}=C_{0}+c_{1}\left(Y_{t, j}-T_{t, j}\right) . & G_{t, j}=G_{t, j}^{0}+g_{1} Y_{t, j} & M_{t, j}=\mu_{j} Y_{t, j} \\ I_{t, j}=I_{0}+d_{1} Y_{t, j}-d_{2} r_{t, j} & T_{t, j}=T_{t, j}^{0}+t_{1} Y_{t, j} & X_{t, j}=\sum_{\substack{i \neq 1 \\ i=1}}^{I} \omega_{i j} \mu_{i} Y_{t, i}\end{array}$

where $\mu_{i}$ is the marginal propensity to import of a trading partner $i, Y_{i}$ is the output of a trading partner $i$, and $\omega_{i j}$ is the weight of imports from country $j$ in total imports of country $i$. Government expenditures and revenues have a cyclical part and a discretionary element. Substituting the definitions (1.2) in (1.1) yields

$$
Y_{t, j}=e x_{t, j}+m_{j} G_{t, j}^{0}+\rho_{G} m_{j} G_{t-1, j}^{0}-m_{j} c_{1} T_{t, j}^{0}-\rho_{T} m_{j} c_{1} T_{t-1, j}^{0}+m_{j} \sum_{\substack{i \neq j \\ i=1}}^{I} \omega_{i j} \mu_{i} Y_{t, i}
$$

Where $e x_{t, j}=C_{0}+I_{0}-d_{2} r_{t, j}$ and $m_{j}=\left(1-c_{1}-d_{1}-g_{1}+t_{1}+\mu_{j}\right)^{-1}$ is the expenditure multiplier. Taking the first difference and dividing by real output in $\mathrm{t}-1$ yields the growth rate:

$$
\frac{\Delta Y_{t, j}}{Y_{t-1, j}}=m_{j}\left(\frac{\Delta G_{t, j}^{0}}{Y_{t-1, j}}+\rho_{G} \frac{\Delta G_{t-1, j}^{0}}{Y_{t-1, j}}\right)-m_{j} c_{1}\left(\frac{\Delta T_{t, j}^{0}}{Y_{t-1, j}}-\rho_{T} \frac{\Delta T_{t-1, j}^{0}}{Y_{t-1, j}}\right)+m_{j} \sum_{\substack{i \neq j \\ i=1}}^{I} \omega_{i j} \mu_{i} \frac{\Delta Y_{i}}{Y_{t-1, i}} \frac{Y_{t-1, i}}{Y_{t-1, j}}
$$

Equation (1.4) is a system of $I$ linear equations that can be written in matrix notation:

$$
\tilde{Y}_{t}=W\left[A_{1} \bar{G}_{t}-A_{2} \bar{T}_{t}\right]
$$

Here $W=(I-B)^{-1}$ is a $I$-by- $I$ identity matrix, B is a $I-b y-I$ matrix, $\tilde{Y}$ is $I-b y-1$ vector of real GDP growth rates, $A_{1}$ and $A_{2}$ are diagonal $I-b y-I$ matrices and $\bar{G}_{t}$ and $\bar{T}$ are $I-b y-1$ vectors. It is possible to derive country $i$ 's contribution to country $j$ 's GDP growth by evaluating:

$$
\tilde{y}_{t, j i}=w^{j i}\left[a_{1}^{j i} \bar{g}_{t}^{i}-a_{2}^{j i} \bar{t}_{t}^{i}\right]
$$

The sample of countries includes: Austria, Belgium, China, Finland, France, Germany, Greece, India, Ireland, Italy, Japan, Korea, Netherlands, Portugal, Russia, Spain, Sweden, Switzerland, United Kingdom, and United States. This sample of countries accounts for more than 80 percent of Belgian exports. The fiscal impulse is measured by the change in the cyclical adjusted revenues and expenditures relative to GDP. Details on the other assumptions are provided in Ivanova and Weber (2011). 


\section{Box I.2. A Simulation Approach for the Downstream Risk from Defaults ${ }^{1}$}

The analysis is based on several rounds of shocks. The first round considers bank losses on assets that deplete their capital partially or fully. The banking sector losses are calculated based on percentage loss assumptions in a particular economic sector (public sector, banking sector, and/or non-bank private sector) of an individual country or group of countries. In the second round, if losses are large enough, a capital ratio is assumed to be restored through deleveraging (loans not being rolled over and selling of assets, assuming no recapitalization). In the third round, banks are assumed to reduce their lending to other banks, causing fire sales, and further deleveraging. Potential bank failures cause additional losses to other banks on the asset and liability sides. Final convergence is achieved when no further deleveraging needs to occur. Methodological details may be described by the following set of equations: ${ }^{2}$

The analysis of the contagion of a crisis across borders and through common lender effects is based on considering a stylized bank balance sheet given by:

$$
\text { Assets }=\text { Capital }+ \text { Other__Liabilitie } s
$$

where Assets $=$ Foreign_Assets + Domestic_Assets. To quantify the effect of a shock on assets, it is assumed that, when facing a loss of LLR percent on its foreign assets, a bank combines asset sales $D E L$ and recapitalization RECAP to maintain a sound capital to asset ratio of $C A R$. For a given loss on its asset portfolio, the set of possible combinations of deleveraging (asset sales) and recapitalization is given by:

Capital $-L L R \cdot$ Foreign_Assets $+R E C A P=C A R \cdot($ Assets $-L L R \cdot$ Foreign_Assets - DEL $)$

Hence, in the absence of a recapitalization of the banking sector, the extent of deleveraging by the financial institutions of a creditor country is given by:

$D E L=$ Assets $-L L R \cdot$ Foreign_Assets $-\frac{1}{C A R} \cdot($ Tier I Capital $-L L R \cdot$ Foreign_Assets $)$

The process of deleveraging results in a global reduction of cross-border claims by all international banks affected by the shock, either directly or indirectly. For each recipient country, the extent of capital outflows is the aggregation of the deleveraging process by all creditor countries. Additional rounds of deleveraging may take place if shocks are large enough to cause international banks' insolvencies, and if fire sales of assets occur, triggering further losses. The system converges to an equilibrium when no further deleveraging takes place.

${ }^{1}$ Prepared by Eugenio Cerutti.

${ }^{2}$ Based on Tressel (2010), and Cerutti, Claessens, and McGuire (20110 


\section{References}

Cerutti, Eugenio, 2011. "Foreign Default Exposures and Rollover Risks: Measurement, Evolution and Determinants", forthcoming IMF Working Paper

Cerutti, E., S. Claessens, and P. McGuire (2011): "Systemic Risks in Global Banking: What Available Data Can Tell and What More Data are Needed," IMF Working Paper 11/222, International Monetary Fund.

Ivanova, Anna and Sebastian Weber, 2011. “Do Fiscal Spillovers Matter?” IMF Working Paper 11/211, International Monetary Fund

Poirson, Helene and Sebastian Weber, 2011. "Growth Spillover Dynamics from Crisis to Recovery”, IMF Working Paper 11/218, International Monetary Fund

Thierry Tressel, 2010. "Financial Contagion through Bank Deleveraging: Stylized Facts and Simulations Applied to the Financial Crisis," IMF Working Papers 10/236, International Monetary Fund 


\section{On A Revenue-Neutral Growth-Oriented Tax Reform For Belgium ${ }^{1}$}

\section{A. Introduction}

\section{Belgium's current economic situation has brought important fiscal policy} questions to the forefront of the policy discussions. Among them, the question of designing tax policy to use it in its full capacity as a tool to preserve fiscal space while balancing the needs for economic growth in a complex environment deserves particular attention.

2. This paper delves into this issue with two main objectives. The first purpose is to provide an overview of the situation of the Belgian tax system, drawing on international comparisons to provide an assessment of its current stance. This will help understand which taxes may need to be revised at the time of deciding to improve the tax system. The paper then explores to what extent a shift in the tax composition may help boost employment and growth while leaving the overall tax-collection level broadly unchanged to preserve fiscal sustainability. In this regard, the paper draws on recent research that emphasizes the strong link that exists between the tax mix and different key economic variables. More specifically, the paper illustrates quantitatively the potential effects of a revenue-neutral change in the composition of taxes on different macroeconomic variables including per capita growth, employment and net exports.

\section{The link between tax composition and economic growth has been extensively} studied in the empirical literature, giving rise to a well-defined 'tax and growth ranking'. In a nutshell, the most preferred taxes from an efficiency standpoint are those that least affect labor and investment-saving decisions. ${ }^{2}$ In this regard, it has been found that recurrent taxes on immovable property (and residential property in particular) are the least distortive tax instrument for growth, followed by consumption taxes (and other property taxes), personal income taxes, and corporate income taxes as the most harmful for growth. ${ }^{3}$ Therefore, a revenue neutral growth-oriented tax reform would involve shifting part of the revenue base from income taxes to consumption and immovable property taxes.

4. The rest of the paper is organized as follows. Section B summarizes the current situation of the Belgian tax system, emphasizing in particular how it compares with other countries in the region. Sections $\mathrm{C}$ and $\mathrm{D}$ then discuss in detail the specifics of the main direct and indirect taxes that are currently in place in Belgium. Section E then illustrates

\footnotetext{
${ }^{1}$ Prepared by Santiago Acosta-Ormaechea.

${ }^{2}$ A relevant caveat arises with those taxes whose objective is to modify the behavior of economic agents owing to the negative externalities that can be associated with certain activities undertaken by them. Environmental taxes are a clear example. In those cases the distortions induced by these taxes are desirable and in fact are the objective of the introduction of the tax policy measure.

${ }^{3}$ See, for instance, Arnold et al (2011).
} 
through a quantitative exercise to what extent a revenue-neutral set of tax policy measures may affect the Belgian economy. Finally, Section F concludes.

\section{B. Overview of the Belgian Tax System}

\section{Belgium's total tax revenue collection stands out as one of the highest among} EU-15 countries. ${ }^{4}$ In fact, at 43.2 percent of GDP in 2009 it stood well above the EU-15 and the OECD averages of 38.4 and 33.8 percent, respectively (Figure II.1). Likewise, other comparator countries such as France, Germany and the Netherlands, which also have high levels of taxation, have been systematically below Belgium's tax collection levels in recent years. ${ }^{5}$ This reflects Belgium's social preferences to maintain a large and active state that provides public goods and social transfers, as is also the case in many other European countries. However, regardless of the overall tax burden and the objectives pursued through this by the country, the question of whether the structure of taxes is 'adequate' to also satisfy key goals such as employment and growth remains open and becomes particularly important in the current context.

6 Belgium's tax structure heavily relies on taxes on income, profits and capital gains, with collection levels notably above EU-15 and OECD averages. Belgium's high reliance on these taxes becomes even more striking when comparing them with the cases of France, Germany and the Netherlands, countries which are currently levying between 6 and 4 percent of GDP less than Belgium in corporate and non-corporate income taxes. Although payroll taxes and social security contributions are more aligned with the levels observed in the three neighboring countries, the overall collection from these taxes still remains about 3 percent and 5 percent of GDP above EU-15 and OECD averages, respectively. These characteristics of the Belgian tax system highlight the significant tax burden that currently exists on labor and business. Interestingly, the collection of taxes on goods and services, and property taxes does not seem to be out of line in Belgium relative to other economies in the region.

\footnotetext{
${ }^{4}$ Following the classification of the OECD Revenue Statistics database the total tax revenue category includes social security contributions.

${ }^{5}$ In 2009 total revenue collection in France, Germany and the Netherlands reached 42.4 percent, 37.3 percent, and 38.2 percent of GDP, respectively.
} 
Figure II.1. Selected Countries: Overall Tax Collection in 2009 (Percent of GDP)

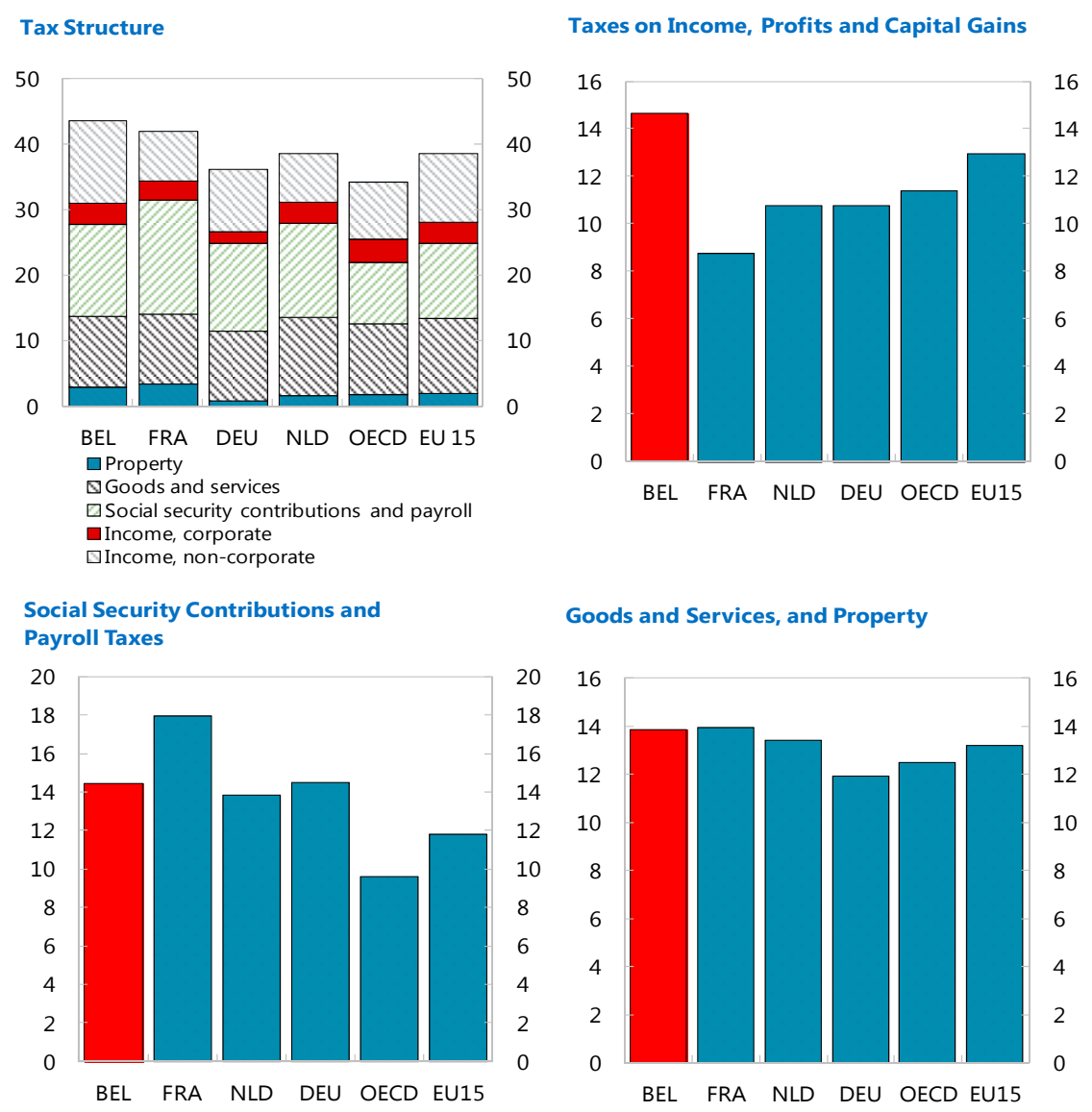

Sources: OECD, Revenue Statistics Database.

7. The Belgian bias toward direct taxation is significant, and it has shown little change over the last 15 years. ${ }^{6}$ As of end-2009 direct taxes in Belgium-excluding social security contributions - reached 16 percent of GDP, a ratio notably above European averages, which stood at 11.5 and 14.2 percent of GDP for the EU-27 and EU-15 countries, respectively. However, indirect taxation in Belgium remained broadly in line with European averages, showing very small changes over the course of the last decade. Although the high relevance of direct taxation is a common phenomenon among advanced economies, the relatively larger preponderance observed in Belgium is remarkable. In fact, according to the latest European Commission (2011) statistical release, as of end-2009 the direct-to-indirect tax ratio in Belgium of 1.2 stood at the high end of the EU-15 countries, and significantly above that of France (0.7), Germany (0.9), and the Netherlands (1).

\footnotetext{
${ }^{6}$ The definition of direct and indirect taxes follows that of the European Commission (2011). Direct taxes include the personal income tax, the corporate income tax and taxes on capital gains. Indirect taxes include the value-added tax, excise duties and consumption taxes, other taxes on products (including import duties) and other taxes on production.
} 


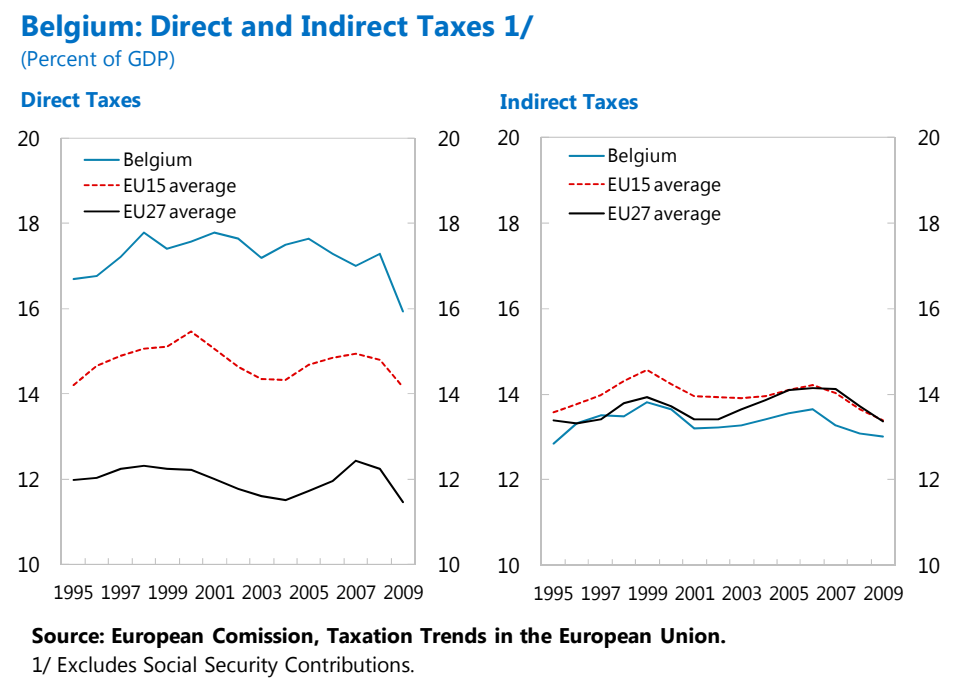

8. A major aspect of the choice of the tax structure is related to its potential impact on the economy through different channels, including employment, growth, income distribution and FDI inflows. In fact, according to different endogenous-growth models, the effects of the tax system on the economy can be highly persistent, owing to the link that exists between tax composition and the accumulation of human and physical capital. ${ }^{7}$ Additionally, the tax composition can affect the income distribution, as certain types of taxes tend to be more progressive than others. ${ }^{8}$ Moreover, the amount of FDI received by a country can also be affected by the tax structure, due to the high degree of economic and financial integration that exist among many economies. Are these effects substantial? In an empirical work considering a panel of 116 countries over the period 1972-2005, Martinez-Vazquez et al (2010) find that a 10 percentage points increase in the direct-to-indirect tax ratio may reduce the GDP per capita growth rate by 0.39 percent, a finding that reflects the potentiallysignificant relevance of the tax mix on the evolution of the economy. ${ }^{9}$

\section{Several reforms, and notably those initiated in the early $2000 \mathrm{~s}$, have attempted} to moderate the bias of the Belgian tax system towards direct taxation but have yielded mixed results (Box 1). Notwithstanding the authorities' initial objectives, the overall effects of these reforms have been relatively modest in terms of producing an effective reduction in the weight of direct taxation and a cutback in labor taxes. In fact, the direct-to-indirect tax ratio decreased moderately from 1.35 in 2001 to 1.23 in 2009. Likewise, the average labor tax wedge decreased only marginally, from 56.6 percent in 2001 to 55.4 in 2010 for a single

\footnotetext{
${ }^{7}$ See Martinez-Vazquez et al (2010) for a discussion.

${ }^{8}$ For instance, property taxes, and in particular immovable property taxes, may have well-regarded effects in terms of favoring a more equal income distribution as they tend to impose a higher burden on the relatively better-off fraction of the population.

${ }^{9}$ The change in the tax mix also reduces FDI inflows (by 0.57 percent) and reduces income inequality by about 1 percentdue to data availability, different countries and sub samples are considered in these two estimations (see Martinez-Vazquez et al, 2010).
} 


\section{Box II.1: The Tax Reform of the Early 2000s}

In the early $2000 \mathrm{~s}$, Belgium implemented a series of measures to reform its tax system, most notably in 2002, to offset the high reliance on direct taxation through reductions in personal income taxes, social security contributions and corporate income taxes. With these measures the authorities aimed at fostering employment and growth through reductions in labor costs, with an estimated loss in revenues of about 1.3 percent of GDP. Key measures included: ${ }^{1}$

- A tax credit for low income earners;

- The streamlining of marginal tax rates on medium income tax brackets;

- The introduction of new work-related tax-deductible expenses;

- A reduction of the top marginal personal income tax rate from 52 percent to 50 percent;

- The introduction of higher tax exemptions on the income of married double-income earning couples, alongside the tax exemptions of unmarried cohabitant couples;

- The separation of non-work related income taxation;

- The promotion of environmentally-friendly taxation; and

- The increase in the tax allowances for dependent children.

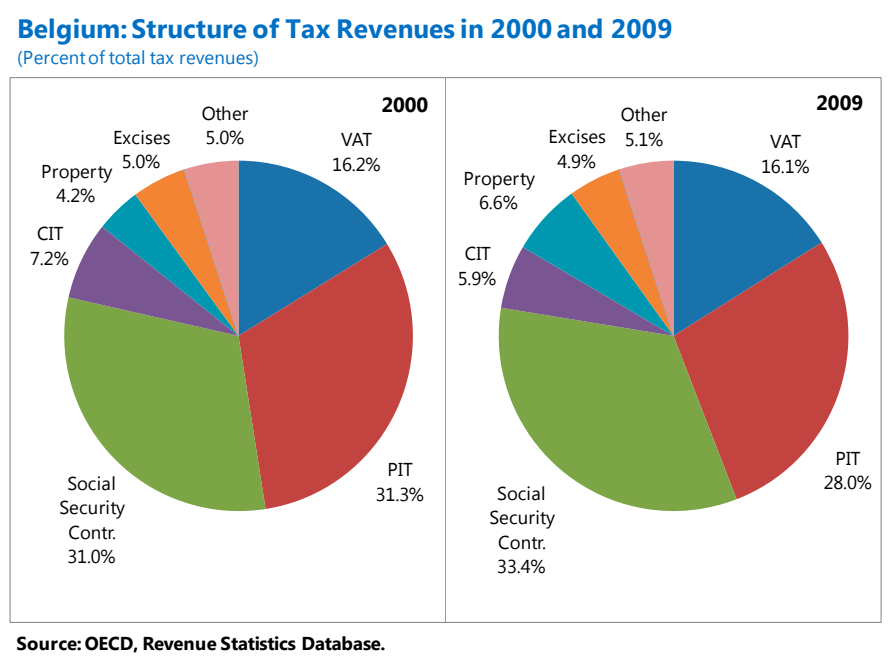

As a consequence of this reform, and most notably after the introduction of the notional interest rate deduction in 2006, the share of the corporate income tax (CIT) in total tax revenue decreased significantly between 2000 and 2009 from 7.2 percent to 5.9 percent. This trend is also observed in the case of the personal income tax (PIT), which went from 31.3 percent of total taxes to 28 percent over the last decade. However, the share of VAT revenues and excises in total collection - a key determinant of total indirect taxes - decreased slightly in the comparison between the two periods, a result that unveils the introduction of several exemptions and reduced rates that negatively affected the performance of these taxes during the last decade. There has been also an upward shift in the participation of property taxes, reflecting a number of measures that boosted their collection. Some increase has taken place regarding the share of social security contributions in total taxation, a source of revenues which still accounts for about one third of total collection.

${ }^{1}$ See Abreu (2004) and Høj (2009) for details. 
worker without children at the average wage. In addition, the reduction in the average personal income tax rates introduced with the tax reform, which was especially targeted to low-earning workers, gave rise to pronounced spikes in marginal labor taxes. This has likely affected the supply of hours in the labor market in a negative way, with a concomitant adverse effect on employment and growth.

10. Moving forward, additional constraints should be taken into account when designing measures to reduce the high tax burden on labor in an enduring way. A key challenge now is the fact that the fiscal space to reduce taxes is rather limited, as a consequence of the fiscal consolidation needs faced by the country. For this reason, any future reform should consider not only reductions in direct taxation but also additional measures that compensate for the loss in revenues associated with lower labor and corporate taxes, for instance through the use of more growth-friendly tax instruments such as consumption, property and environmental taxes.

\section{Labor and Business Taxation}

\section{Personal income tax, social security contributions and the tax wedge}

11. Although the top statutory PIT rate in Belgium has substantially decreased after the early 2000s, it still remains at the high end of the EU-15. In fact, in 2009 it reached 53.7 percent of the average wage for a single individual worker without children, roughly 10 percentage points below that of 2000 (63.9 percent). Despite this reduction, Belgium's still high statutory rate is reflected in the fact that PIT contributions as a share of the average wage is currently the highest among EU-15 countries. Nevertheless, the overall yield on this tax has been more aligned with the levels observed in other advanced economies. This is a direct consequence of widespread deductions and exemptions, which have severely undermined the overall PIT tax base in Belgium. ${ }^{10}$

\footnotetext{
${ }^{10}$ Other factors such as tax evasion and fraud may also play a role in undermining the overall tax base in Belgium, notably in the cases of the PIT and VAT.
} 

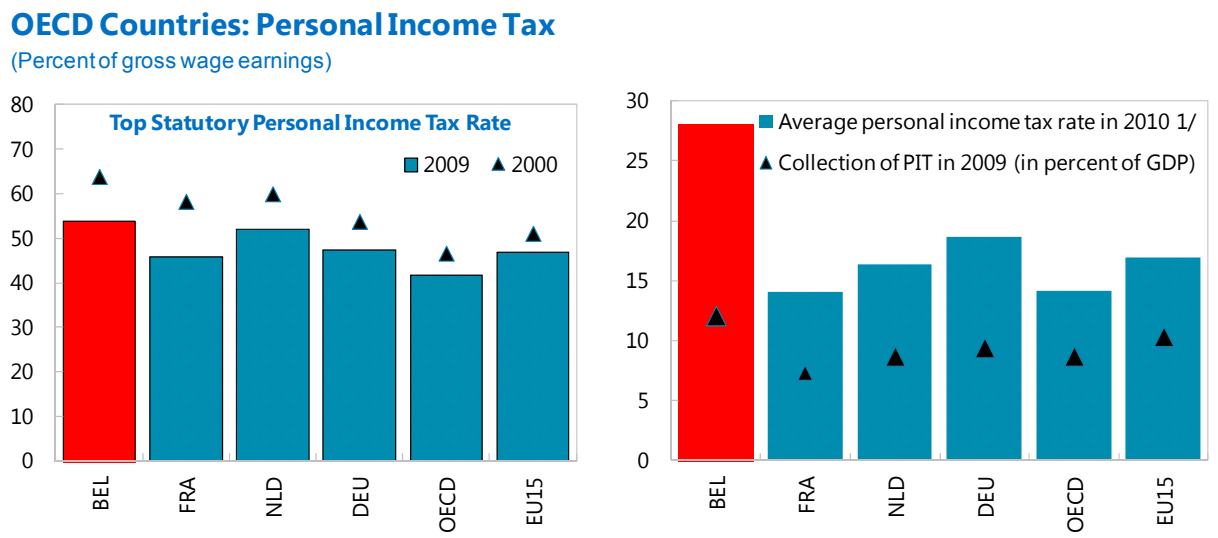

Source: OECD, Taxing Wages Database.

1 /For a single individual worker without children, at the income level of the average worker.

12. The high social security contributions (SSCs) have also contributed to the fact that labor costs are about the highest in the EU-15. Although the fraction of SSCs covered by employees has not been far from other EU-15 countries in recent years, the fraction covered by the employer has notably been above EU-15 or OECD levels, and is surpassed only by France among the three big neighboring countries. For this reason, the overall SSCs as a fraction of the average wage in Belgium remained well above the EU-15 average in 2010-yet

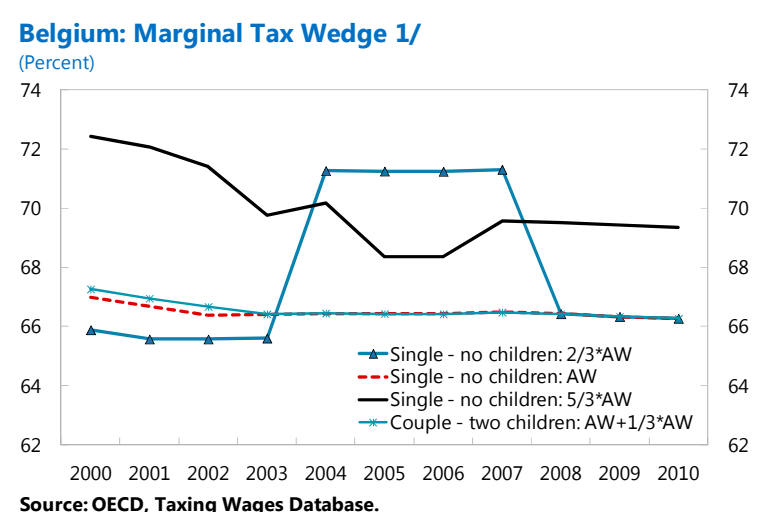
Source: OECD, Taxing Wages Database. $1 / \mathrm{AW}=$ Full-time job average wage in the private sector. showing a slight downward trend since the beginning of the decade.

OECD Countries: Social Security Contributions and Total Tax Wedge in 2010
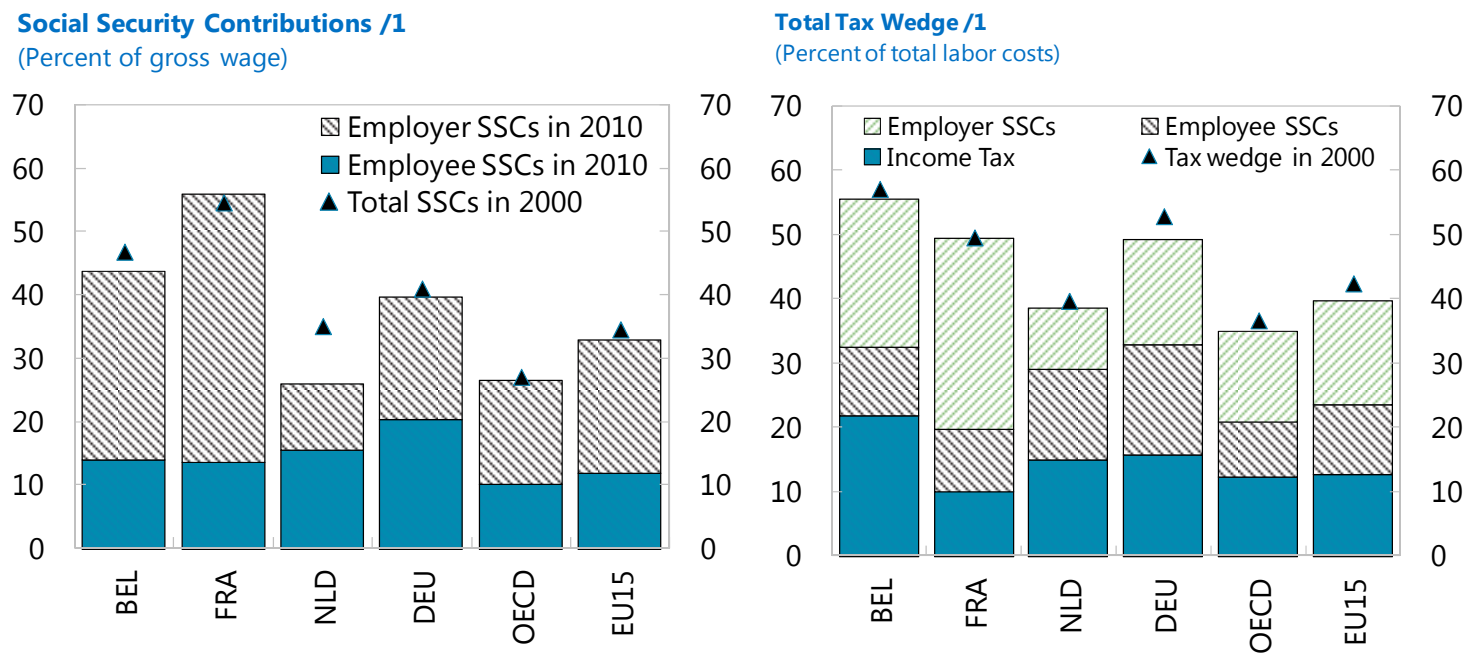

Source: OECD, Taxing Wages Database.

1/ For a single individual worker without children, at the income level of the average worker. 


\section{As a consequence of the high PIT and SSCs, the labor tax wedge in Belgium} in 2010 was the highest in the OECD for an average worker. More striking is the fact that for a single worker at average earnings it stood roughly 6 percentage points above France and Germany, the two countries that immediately follow Belgium in this ranking. Moreover, despite the reductions in the statutory PIT rates observed in the last 10 years, there has been almost no modification in the level of the tax wedge relative to where it was a decade ago. This highlights the pressing need for more sweeping measures to reduce the high tax burden on labor that currently exists in the country. In fact, the average tax wedge has either been the highest or the second highest in the OECD considering all the different types of the labor wage earnings described in the OECD taxing wages database for the year 2010. A similar pattern has been observed in the case of the marginal tax wedge, as it has been systematically at the top of the OECD over the last decade. The combination of a high average and marginal labor tax wedge has discouraged employment through its negative impact on the decision to work (extensive margin) and the number of hours offered in the market (intensive margin), thus hampering long-run growth.

OECD countries: Average Labor Tax Wedge in 2010 1/

\begin{tabular}{|c|c|c|c|c|c|c|c|}
\hline & & BEL (rank) & FRA & NLD & DEU & OECD & EU15 \\
\hline \multirow[t]{3}{*}{ Single - no children } & $2 / 3^{*} \mathrm{AW}$ & $49.5(1 / 34)$ & 45.5 & 33.7 & 44.9 & 31.3 & 36.2 \\
\hline & AW & $55.4(1 / 34)$ & 49.3 & 38.4 & 49.1 & 34.9 & 39.6 \\
\hline & $5 / 3^{*} \mathrm{AW}$ & $60.6(1 / 34)$ & 53.2 & 42.3 & 51.5 & 39.4 & 44.6 \\
\hline Single - two children & $2 / 3^{*} \mathrm{AW}$ & $34.8(2 / 34)$ & 37.2 & 12.0 & 29.7 & 15.7 & 22.9 \\
\hline \multirow[t]{3}{*}{ Couple - two children } & $A W+0 * A W$ & $39.6(2 / 34)$ & 42.1 & 31.1 & 32.6 & 24.8 & 31.7 \\
\hline & $A W+1 / 3^{*} A W$ & $40.9(1 / 34)$ & 39.7 & 29.7 & 37.7 & 26.9 & 32.3 \\
\hline & $A W+2 / 3^{*} A W$ & $47.8(1 / 34)$ & 44.3 & 32.1 & 41.4 & 29.7 & 34.7 \\
\hline Couple - no children & $A W+1 / 3^{*} A W$ & $47.7(1 / 34)$ & 45.4 & 34.4 & 44.9 & 31.9 & 37.0 \\
\hline
\end{tabular}

$1 / \mathrm{AW}=$ Average Worker: average wage in a manual and non-manual full-time job in the private sector for all workers. Source: OECD, taxing wages database.

\section{Corporate income tax}

14. Although the statutory CIT rate in Belgium was reduced in the 2002 tax reform, it still remains high by regional standards. It stood at 34 percent in 2011, down from 40.2 percent in 2000 , a figure about 7.5 percentage points above the EU-15 average. Moreover, the Belgian's CIT rate is currently significantly above that of Germany (30.2 percent) and the Netherlands (25 percent). Notwithstanding the high CIT statutory rate, the yield on this tax has been aligned with other EU-15 countries - with a total collection in Belgium of 2.5 percentage of GDP as of 2009, roughly 0.2 percent of GDP above the EU-15 average. Different tax benefits and exemptions explain the relatively low yield of the CIT, including: 
- The notional interest deduction. This allowance permits companies to deduct from their tax base a notional amount of interest based on the 10-year government bond yield before the current tax year. ${ }^{11}$ The total amount that can be deducted also includes a cap, which is established by law. The notional interest rate deduction has been successful in reducing the bias towards debt financing, owing to the deduction of the interest payments on debt. In that sense, Belgium's tax regime allows for a more evenly-distributed funding source between equity and debt across firms relative to other comparator OECD countries, thus helping improve the allocation of investment projects more efficiently with its concomitant positive effects on employment and growth. ${ }^{12}$

- Several investment projects benefit from additional tax credits, notably in the area of research and development. In addition, a special tax regime applies to SMEs regarding investment deductions. However, as highlighted in Høj (2009), the presence of lower rates and special deductions for SMEs may lead to other specific distortions, as these firms may avoid increasing their size to the optimal level for tax reasons, thus affecting employment and growth.

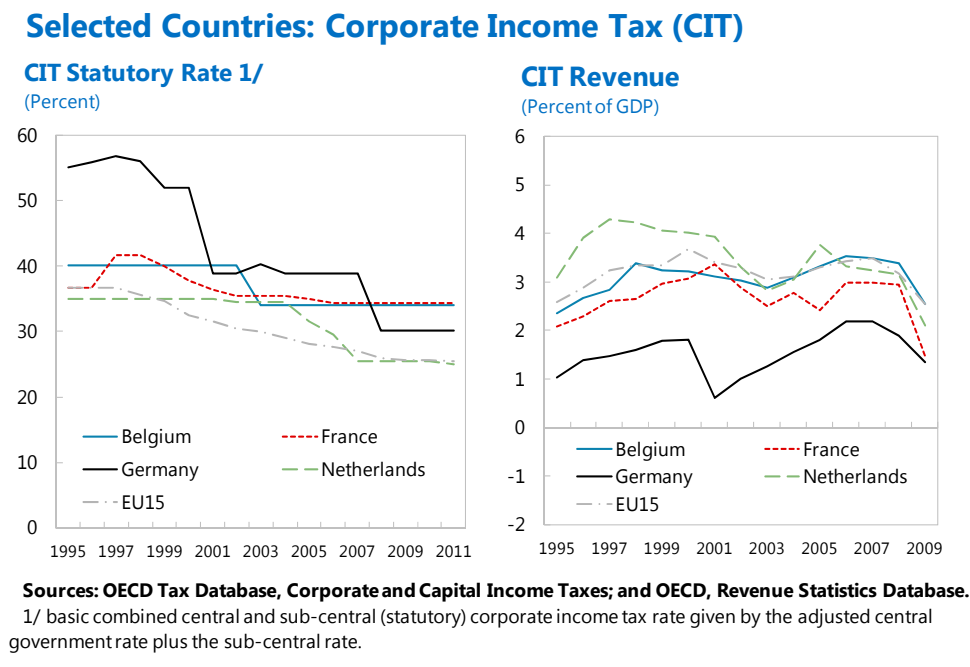

\section{Brief Overview of Other Key Taxes in Belgium}

\section{$\boldsymbol{V A T}$}

\section{The standard VAT rate in Belgium at 21 percent is high by European standards, and above that of Germany (19 percent), France (19.6 percent) and the Netherlands}

\footnotetext{
${ }^{11}$ For the assessment years 2011 and 2012, the rates are set at 3.8 percent and 3.4 percent, respectively. For SMEs these rates are increased to 4.3 percent and 3.9 percent.

${ }^{12}$ See de Mooij (2011) for a summary of the potential quantitative effects of the interest rate deductibility on key macroeconomic variables, including employment and growth.
} 
(19 percent). However, the total VAT collection at 7 percent of GDP is somewhat below the EU-15 average of 7.3 percent, and below the levels of Germany (7.1 percent) and the Netherlands ( 7.2 percent), but is broadly in line with that of France ( 7 percent). In addition, the VAT revenue ratio-defined as total VAT revenue relative to its potential base - stood at 0.49 by end-2008, a ratio similar to that of France but notably below the EU-15 average (0.55), Germany (0.55) and the Netherlands (0.60). Widespread exemptions and reduced rates in Belgium mostly explain the reduced VAT base and its relatively lower yield.

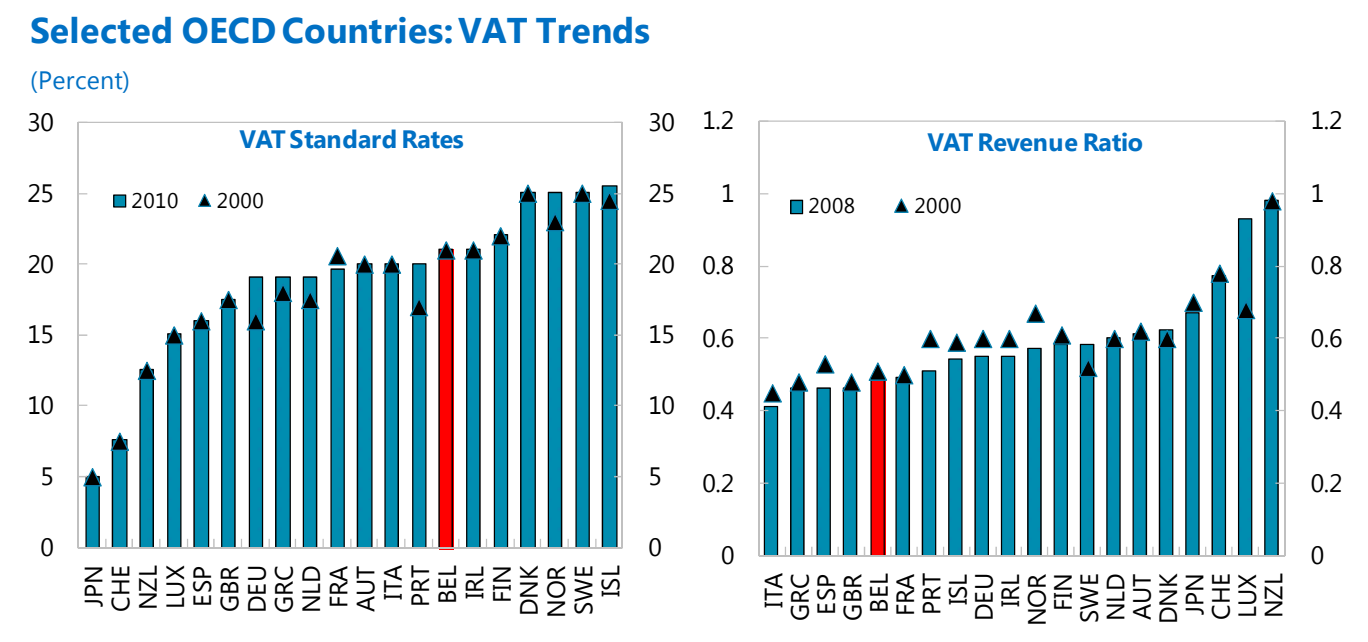

Source: OECD, 2010, Consumption Tax Trends.

16. Besides the standard 21 percent rate, three other rates currently coexist in the country. There is a 6 percent rate applying to public housing, refurbishment of old housing, food, water, pharmaceuticals, animals, art and publications and some labor intensive services. There is also an intermediate 12 percent rate applying to a limited number of transactions and food in restaurants and catering services. Finally, there is a zero rate on newspapers and certain weeklies. It follows from the relatively lower yield on the VAT that a full revision of its structure, including the elimination of exemptions and reduced rates could be considered, notably through the equalization of all rates with the statutory rate. The underlying social objectives of a differentiated VAT rate structure may be instead pursued through other fiscal instruments such as well-targeted transfers.

\section{Property taxes}

17. Property taxes have efficiency-enhancing characteristics relative to other tax instruments, which essentially stem from the immobility of its tax base. They are also less distortive than other taxes in terms of the allocation of resources in the economy, since they do not tend to affect investment-savings decisions, thereby helping preserve long-run growth. They also have important properties in terms of tax progressivity, since property values and income tend to be positively correlated.

18. Although Belgium levied 2.9 percent of GDP in property taxes in 2009, a figure similar to that of other key EU-15 economies, the breakdown of these taxes differed substantially from other countries in the region. In particular, property taxes in Belgium 
rely substantially on taxes on financial and capital transactions, which currently yield taxation levels significantly above the EU-15 average. Similarly, estate and inheritance taxes are at the high end of the EU-15, and notably above that of France, Germany and the Netherlands. Although immovable property taxes at 1.2 percent of GDP are more aligned with the OECD average, the yield on these taxes is notably below the level observed in France (2.4 percent of GDP) and other major OECD countries such as the United Kingdom (3.5 percent of GDP) and the United States (3.1 percent of GDP). Outdated property values explain to a large extent the relatively lower performance of immovable property taxes (see Нøj, 2009).

OECD Countries: Structure of Property Taxes in 2009

(in percent of GDP)

\begin{tabular}{|c|c|c|c|c|c|c|}
\hline & BEL & FRA & NLD & DEU & OECD & $\overline{E U 15}$ \\
\hline Recurrent taxes on immovable property & 1.2 & 2.4 & 0.7 & 0.5 & 1.1 & 1.0 \\
\hline Estate and inheritance taxes & 0.6 & 0.4 & 0.3 & 0.2 & 0.1 & 0.2 \\
\hline Recurrent taxes on net wealth & 0.1 & 0.2 & 0.0 & 0.0 & 0.1 & 0.2 \\
\hline Taxes on financial and capital transactions & 0.9 & 0.4 & 0.5 & 0.2 & 0.4 & 0.5 \\
\hline Other taxes on property & 0.1 & 0.0 & 0.0 & 0.0 & 0.1 & 0.1 \\
\hline Total & 2.9 & 3.4 & 1.5 & 0.9 & 1.8 & 1.9 \\
\hline
\end{tabular}

Source: OECD, Revenue Statistics Database.

\section{Environmental taxes}

19. Environmental taxes represent an important source of tax collection that can be further exploited in the country. In 2009, Belgium collected 2 percent of GDP in environmental taxes, a figure notably below broad EU averages. In addition, the comparison with the Netherlands becomes particularly striking in this regard, since that country currently levies twice as much as Belgium in environmental taxes. The higher tax collection of energy, transport and pollution taxes in the Netherlands vis-à-vis Belgium largely explains the observed crosscountry differences. More generally, there seems to be space to increase energy and fuel

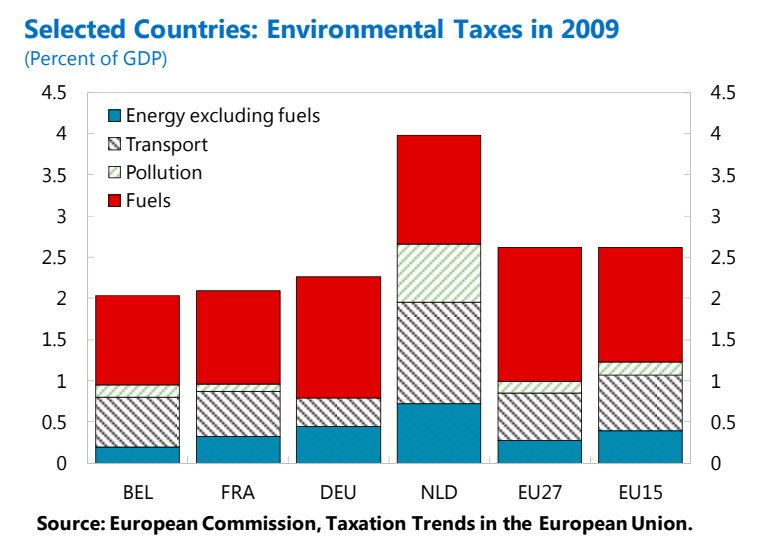
taxes in Belgium, which currently stand out as being particularly low by EU-15 standards.

\section{Tax expenditures}

20. Tax expenditures may impose important costs to society, thus calling for a careful examination. Although countries generally rely on tax expenditures to promote investment projects (e.g., R\&D), the consumption of certain goods (e.g., charitable gifts) or 
to increase tax progressivity (e.g., reduced food VAT rates), which could support important policy objectives, they are also subject to substantial drawbacks. Among them stands out their poor transparency and accountability, and the fact that they generally tend to be poorly targeted while adding significant complexities to the tax system (IMF, 2011a; OECD, 2010b). Moreover, due to the associated loss in tax collection additional pressures in other taxes arise to compensate for the foregone revenues associated with tax expenditures.

\section{Belgium's tax expenditures are widespread and currently represent about}

2.9 percent of GDP. ${ }^{13}$ By regional standards these levels appear to be at the high end of the spectrum, as they are above the levels observed in France (2.2 percent of GDP), Germany (1 percent of GDP) and the Netherlands (1.8 percent of GDP) for similar years. Although it is difficult to set an adequate target for them from a normative viewpoint, a reduction of tax expenditures to a level similar to that of Germany appears to be desirable to gain fiscal space. $^{14}$

\section{E. A Possible Scenario for a Revenue-Neutral Tax Reform in Belgium}

\section{This section discusses a set of measures that could be implemented in Belgium to} reform the tax system in a revenue-neutral manner to help boost employment and growth. There are two main pillars in the proposed reform: (i) it will be revenue neutral, in the sense that the overall tax pressure will broadly remain at the current level, and therefore the current fiscal stance will be essentially unaffected; and (ii) it will involve a change in the tax composition, given by a reduction in labor taxes fully compensated by an increase in taxes that have a less harmful effect on economic activity. Specifically, consumption and property taxes, which generally have lower negative effects on growth, could be raised vis-àvis labor taxes. Environmental taxes could also be increased to gain further fiscal space, since they have desirable effects in terms of the allocation of resources in the economy. In addition, net exports will tend to increase through the rise in the domestic price of imports vis-à-vis exports, essentially through a fiscal devaluation mechanism. ${ }^{15}$

\footnotetext{
${ }^{13}$ The breakdown of tax expenditures is roughly given by: PIT (1.7 percent of GDP), CIT ( 0.8 percent of GDP) and VAT (0.4 percent of GDP). See OECD (2010b) for details.

${ }^{14}$ Tax expenditures on PIT in Belgium at 1.7 percent of GDP are significantly above the levels observed in France (0.8 percent of GDP), Germany ( 0.6 percent of GDP) and the Netherlands ( 1 percent of GDP). These large tax expenditures are essentially associated with the exemptions and reduced rates for social benefits and pensions (see OECD, 2010b).

${ }^{15}$ See IMF (2011b) for details.
} 


\section{Belgium could raise the yield on a number of key taxes to provide around} 3.8 percent of GDP in additional revenues. Simple indicative calculations suggest that these extra revenues can be obtained as follows (Table 1$):^{16}$

- An increase in VAT efficiency: increasing the VAT revenue ratio from 0.49 to the OECD average of 0.58 through the elimination of reduced rates and exemptions would bring about 1.3 percent of GDP in additional revenues.

- An increase in environmental taxes: the willingness to preserve the environment of the Belgian society suggests that these taxes can likely be between the EU-15 and the Netherlands levels - 2.6 and 4 percent of GDP, respectively-essentially through increases in fuel and energy taxes.

- An increase in immovable property tax collection: although it is difficult to evaluate the potential collection of this tax due to data availability, using as a benchmark the average of the best 20 OECD performers - 1.6 percent of GDP - it appears that Belgium could be able to obtain additional revenues in the order of 0.4 percent of GDP through a reassessment of property values. This in turn will help reduce the gap with other key OECD countries such as France, the United Kingdom and the United States, which as of end-2009 are collecting on average 3 percent of GDP regarding these taxes.

- A reduction of tax expenditures: a careful elimination of those tax expenditures associated with the personal and corporate income taxes which are not necessarily well targeted, could further expand the tax base to yield 1 percent of GDP in additional revenue to reach levels closer to those observed in Germany.

24. The additional revenue should be used to reduce the labor tax wage. According to a number of illustrative estimations, the tax wedge could be reduced up to 10 percentage points to reach a level closer to that of the EU-15 without affecting the overall fiscal stance. To ensure that labor demand is boosted more effectively, the reduction in the tax wedge should target a cutback in employers' social security contributions. In terms of the potential revenue losses, a tax wedge reduction of 6 percentage points would imply a loss of about 2.3 percent of GDP, whereas a more aggressive reduction of 10 percentage points would entail a revenue loss of roughly 3.8 percent of GDP. Accordingly, the direct-to-indirect tax ratio will be endogenously affected, falling from 2.34 to either 1.94 or 1.84 depending on the extent of the tax wedge reduction. ${ }^{17}$

\footnotetext{
16 This exercise provides a number of back-of-the envelope calculations that are useful to evaluate the potential gains of the different tax-policy measures, and as such they are meant to be only indicative. For simplicity, second-round effects have been ignored. For further research it could be desirable to undertake a more detailed estimation of the potential effects of these measures.

${ }^{17}$ For this assessment of the direct-to-indirect tax ratio the composition of direct and indirect are slightly redefined in order to align this ratio to that considered in the estimations of Martinez-Vazquez et al (2010). Specifically, using the classification of the Revenue Statistics database of the OECD direct taxes are defined as the sum of: taxes on income, profits and capital gains; social security contributions; taxes on payroll and workforce; and taxes on property. Indirect taxes are defined as the sum of: taxes on goods and services; and other taxes.
} 
Table II.1. Illustrative Quantification of Proposed Tax Measures (Percent of GDP)

\begin{tabular}{|c|c|}
\hline Measures to gain fiscal space & $\begin{array}{l}\text { Potential gains in } \\
\text { revenue collection }\end{array}$ \\
\hline Value added tax & 1.3 \\
\hline Elimination of reduced rates and exemptions to reach OECD VAT efficiency level & 1.3 \\
\hline Environmental taxes & 1.0 \\
\hline Energy excluding fuels at EU15 level & 0.2 \\
\hline Fuel taxes at EU15 levels & 0.3 \\
\hline Other enviromental taxes to reduce gap with the Netherlands & 0.5 \\
\hline Property taxes & 0.4 \\
\hline Immovable property tax to reduce gap with key OECD countries & 0.4 \\
\hline \multicolumn{2}{|l|}{ Elimination of key tax expenditures (to reach German levels of tax expenditures): } \\
\hline Personal income tax expenditures (excluding those associated with social benefits) & 0.9 \\
\hline Corporate income tax expenditures (excluding notional interest rate deduction) & 0.1 \\
\hline Total & 3.8 \\
\hline Measures to reduce the tax wedge & $\begin{array}{l}\text { Potential loss in } \\
\text { revenue collection }\end{array}$ \\
\hline \multicolumn{2}{|l|}{ Scenario (i): Reduction in the tax wedge by 6 ppts through: } \\
\hline Reduction in employers' social security contributions component by 6 ppts & 2.3 \\
\hline Total & 2.3 \\
\hline \multicolumn{2}{|l|}{ Scenario (ii): Reduction in the tax wedge by 10 ppts through: } \\
\hline Reduction in employers' social security contributions component by 10 ppts & 3.8 \\
\hline Total & 3.8 \\
\hline Impact on direct-to-indirect tax ratio (level) 2/ & $\begin{array}{c}\text { Situation after reform } \\
\text { (pre-reform) }\end{array}$ \\
\hline Scenario (i) & $2.36(2.93)$ \\
\hline Scenario (ii) & $2.30(2.93)$ \\
\hline
\end{tabular}

1/ Labor wedge measure as a percent of total labor costs.

2/ Includes social security contributions.

Source: IMF staff calculations.

\section{Estimations suggest that the impact on unemployment, per capita growth, and} net exports can be significant. Abstracting from second-round effects, a partial equilibrium assessment of the long-run impact of such measures provides the following results: 
- Drawing on standard estimations of elasticities for OECD countries, the reduction in the tax wedge could lead to a reduction in unemployment of up to 2.8 percentage points over the medium term depending on the extent of the tax wedge reduction. ${ }^{18}$

- Estimations for the elasticity of output growth to the tax mix taking into account the uncertainties existing in such estimations suggest that GDP per capita growth can be boosted in the range of 0.5 to 1.2 percent over the long run, with mid-point estimates in the order of 0.8 percent. $^{19}$

- The implicit reduction in the domestic price of exports vis-à-vis imports, associated with the lower tax wedge and the concomitant increase in the VAT burden, suggests that net exports could be increased up to 3.9 percent over the long run through the socalled fiscal devaluation mechanism. ${ }^{20}$

Table II.2. Illustration of Long-run Effects of Proposed Measures on Key Macroeconomic Variables 1/

(Percentage points)

Effect on unemployment rate through reduction in labor wedge

Scenario (i) $\quad-1.7$

Scenario (ii) $\quad-2.8$

Effect on GDP per capita growth rate through change in direct-to-indirect tax ratio

$\begin{array}{ll}\text { Scenario (i) } & 0.8\end{array}$

$\begin{array}{ll}\text { Scenario (ii) } & 0.8\end{array}$

Effect on net exports to GDP ratio through fiscal devaluation mechanism

Scenario (i) $\quad 2.1$

Scenario (ii) $\quad 3.9$

1/ Scenario (i): Reduction in the tax wedge by 6 ppts. Scenario (ii): Reduction in the tax wedge by 8 ppts. Source: IMF staff calculations.

\section{F. Concluding Remarks}

\section{Labor taxation in Belgium is currently about the highest in the OECD, thus} suggesting the need for a sweeping reduction in labor taxes as a key mechanism to boost employment and growth. A main challenge for Belgium under the current circumstances is,

\footnotetext{
${ }^{18}$ See Bassanini and Duval (2006) for details on the estimations for OECD countries. Results from the paper indicate that a 10 percentage points reduction in the tax wage can reduce unemployment in an average OECD country by about 2.8 percent.

${ }^{19}$ For panel data estimations of these elasticities see Arnold et al (2011) and Martinez-Vazquez et al (2010).

${ }^{20}$ See IMF (2011b) for details of these estimations. The analysis considered there suggests that a revenue shift of one point of GDP from employer's social security contributions to VAT could lead to an increase in net exports of $0.443(=2.242-$ 1.799) points of GDP for an average Euro-area country. It is worth mentioning that this result strongly depends on the assumption that nominal wages are fixed in the short run, an assumption that is followed here for convenience.
} 
however, the fact that the fiscal space to reduce taxes is rather limited, owing to the fiscal consolidation needs faced by the country. For this reason, any reduction in labor taxes should be accompanied by a concomitant increase in those taxes that are less harmful for growth in order to preserve fiscal sustainability over the medium term. In this regard, the paper has laid out a proposal for a tax reform which consists of a significant reduction in employers' social security contributions, financed through an increase in the VAT tax base, an increase in environmental and immovable property taxes and a targeted elimination of tax expenditures. Simple back-of-the-envelope calculations suggest that such a reform could entail significant gains in terms of employment and growth over the medium term, without affecting the fiscal stance of the country. Moving forward, it remains to be determined in more detail what the quantitative effects of these measures can be and how to engineer such a reform considering the political constraints faced by the country. 


\section{References}

Abreu, Orlando, 2004, "Income tax reform in Belgium: a free lunch?", ECFIN Country Focus, Volume 1, Issue 14, European Commission.

Arnold, J., B. Brys, Ch. Heady, Å. Johansson, C. Schwellnus and L. Vartia, 2011, "Tax Policy For Economic Recovery and Growth", The Economic Journal, 121, pp. F59-F80.

Bassanini, A. and R. Duval, 2006, "Employment Patterns in OECD Countries: Reassessing the Role of Policies and Institutions", OECD Economics Department Working Papers, No. 486.

de Mooij, R. A., 2011, “Tax Biases to Debt Finance: Assessing the Problem, Finding Solutions," IMF Staff Discussion Note SDN/11/11 (Washington).

de Mooij, R. A. and S. Ederveen, 2009, “Corporate Tax Elasticities: a Reader's Guide to Empirical Findings," Oxford Review of Economic Policy, Vol. 24, No. 4, pp. 680-97.

Høj, Jens, 2009, "How to Reform the Belgian Tax System to Enhance Economic Growth," OECD Economics Department Working Paper No. 741.

European Commission, 2011, Taxation Trends in the European Union, European Union Publishing.

IMF, 2010a, From Stimulus to Consolidation: Revenue and Expenditure Policies in Advanced and Emerging Economies.

,2010b, A Fair and Substantial Contribution by the Financial Sector. , 2011a, Fiscal Monitor-Shifting Gears: Tackling Challenges on the Road to

Fiscal Adjustment, April (Washington: International Monetary Fund). , 2011b, Fiscal Monitor-Addressing Fiscal Challenges to Reduce Economic Risks, September (Washington: International Monetary Fund).

Martinez-Vazquez J., V. Vulovic, and Y. Liu, 2009, "Direct versus Indirect Taxation: Trends, Theory, and Economic Significance," Working Paper 09-11, the Andrew Young School of Policy Studies, Georgia State University.

OECD, 2010a, Tax Policy Reform and Economic Growth, OECD Publishing. OECD, 2010b, Choosing a Broad Base - Low Rate Approach to Taxation, OECD Publishing.

Poirson, Hélène, 2011, "Toward a Growth-Oriented Tax System for France," in France: Selected Issues, IMF Country Report No. 11/212 (Washington). 


\section{TOWARDS JOb-Creating LABOR MARKET REFORM ${ }^{1}$}

1. The new government program aims to raise the share of employed persons in the working age population by 5 percentage points from 67.6 percent in 2010 to

73.2 percent by 2020. The share of the employed in the working age population is below that in most EU peers. Belgium's low employment rate is a constraint to growth and weakens public finances. It is a result of both relatively high unemployment among the labor force and a relatively low labor market participation rate. The unemployment benefit system grants wide access to modest benefits while the pension system allows early exit from the labor market. The reforms agreed in December 2011 are a first step in reforming the benefit system that can be built upon to bring it more in line with EU standards, and provide incentives to boost activity.

2. This note proceeds in the following manner. Section A illustrates the key characteristics of the Belgian labor market, especially highlighting the dispersion in regional unemployment rates and low participation rates. Sections B and C describe the key elements of the unemployment and pension benefit systems, focusing on some of the labor market incentives inherent in the system. In December 2011, the government announced a series of labor market reform initiatives, which will also be sketched out in Sections B and C. Section $\mathrm{D}$ includes a brief overview of the active labor market policies pursued by the various levels of government while Section E illustrates some impediments to labor mobility. Section $\mathrm{F}$ takes a first cut at estimating the impact of the unemployment benefit system on regional employment in a regional panel data set. Section $\mathrm{G}$ concludes and makes some policy recommendations.

\section{A. Characteristics of the Labor Market}

3. Owing to weak labor market participation, employment accounts for a relatively small share of the working age population by eurozone standards. For example, the unemployment rate in 2010 was somewhat below the euro area average. This, however, did not translate into a higher employment rate than the euro area average because labor market participation was weak: At $673 / 4$ percent, the overall activity rate in 2010 was well below the eurozone average (71 $1 / 2$ percent). Despite an increase over the past two decades, low labor force participation by EU standards has been a persistent feature of the Belgian labor market. Throughout the decade from 2001-10, Belgium's activity

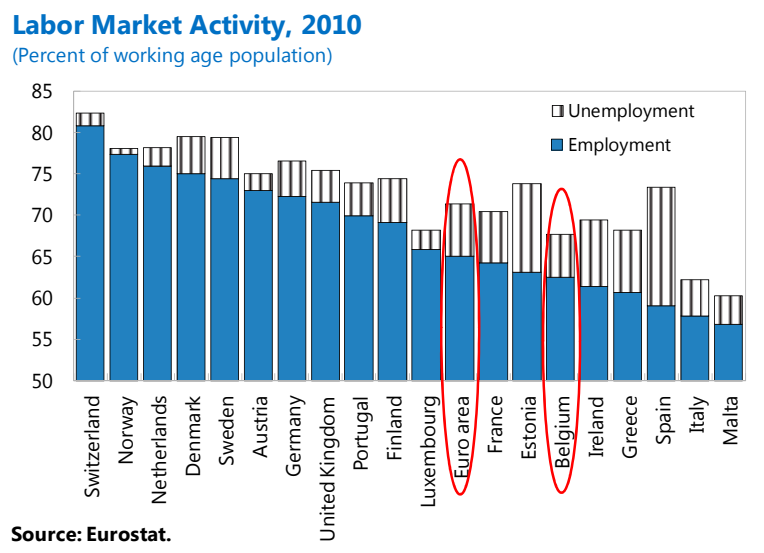

\footnotetext{
${ }^{1}$ Prepared by Franziska Ohnsorge.
} 
rate has been $3 \frac{1}{4}-4 \frac{1}{2}$ percentage points point below the euro area average. Within the eurozone, only Italy, Malta, Greece, Portugal, and Luxembourg have at times shown lower activity rates.

4. During the most recent downturn, employment growth has held up well, reflecting government support. Belgium has a large public sector and makes extensive use of employment subsidies in various forms. As a result, public employment (in public administration, education, or the government-supported health sector) and subsidized or supported employment (including workers on subsidized part-time employment and service voucher workers) have accounted for more than ninety percent of all employment growth from 2000 to $2010 .^{2}$ During the most recent downturn of 2007-10, public and publicly supported employment growth has partially compensated for employment losses in the private sector.
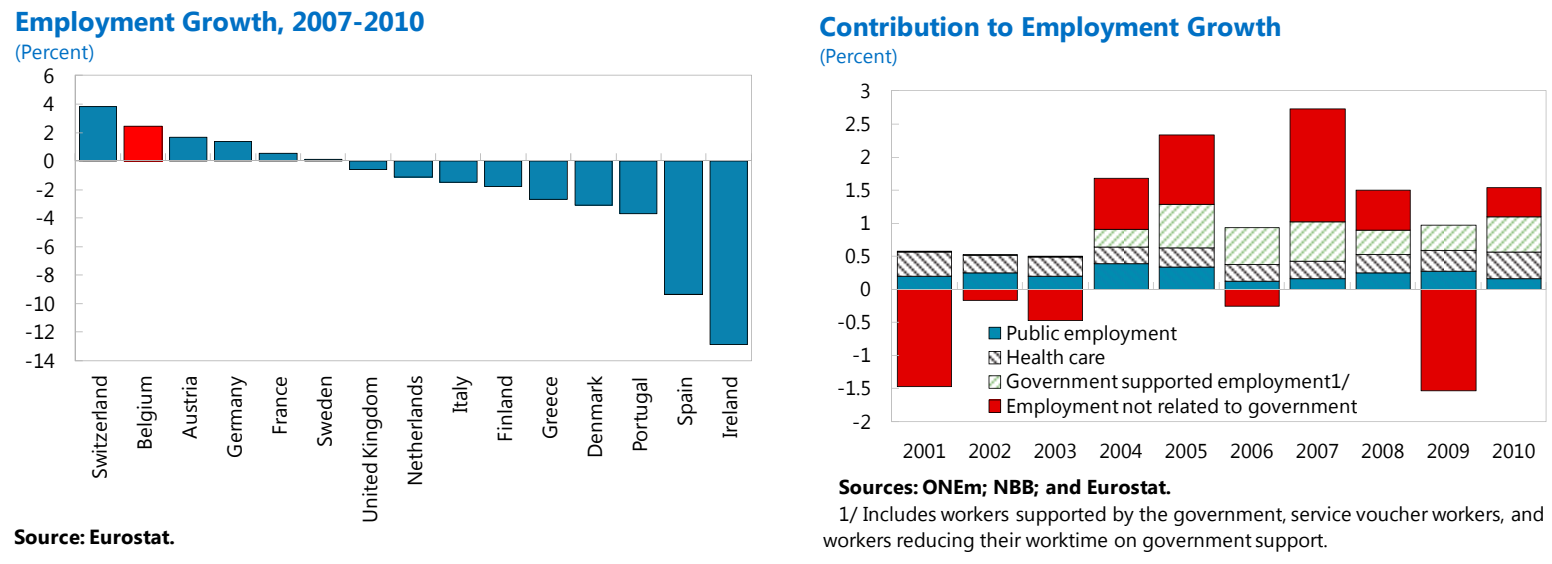

\section{The dispersion of unemployment rates is, by EU standards, exceptionally large}

in Belgium. In 2010, unemployment rates ranged from 3.8 percent in West-Flanders to 17.3 percent in Brussels. Only Spain and France, both about twenty times Belgium's size by area, have a greater regional dispersion in unemployment rates. ${ }^{3}$ Within regions, the dispersion of unemployment rates in Wallonia is as high as that of Portugal and that in Flanders as low as that in Sweden. The dispersion in regional unemployment rates is most pronounced among young workers below the age of 30 . The highest youth unemployment rates are in communities in Brussels and Wallonia. In contrast to other EU member countries, including the neighboring countries, there has been no significant convergence in unemployment rates over the past decade.

\footnotetext{
${ }^{2}$ Government-supported employment is assumed to include workers on service vouchers, those employed but supported by ONEm, and those employed part-time with ONEm support. Workers on service vouchers are typically workers who provide services to private households, such as cleaning. In 2004, these services are encouraged by consumer subsidies and preferential tax treatment, thus drawing many of them from the informal economy into the formal sector.

${ }^{3}$ The standard deviation of unemployment rates scales the comparison by the number of regions, which are significantly fewer in Belgium than in France and Spain.
} 
Regional Unemployment Rates, 2010

(NUTS 2 level, percent)

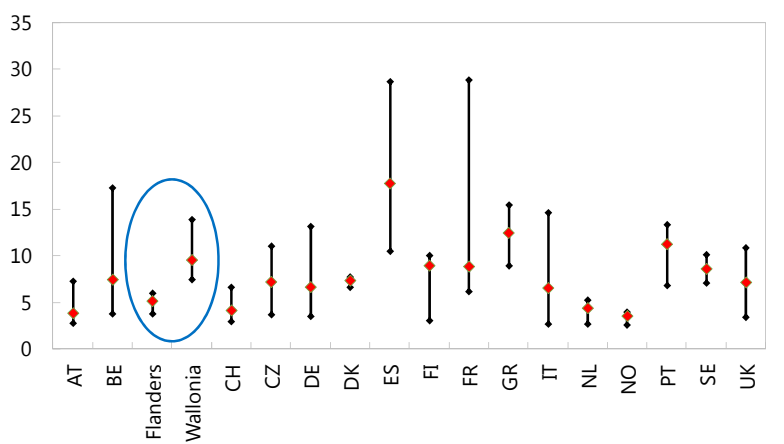

Source: Eurostat.

Dispersion in Regional Unemployment Rates by Age Group, 2010

(Percent of labor force)

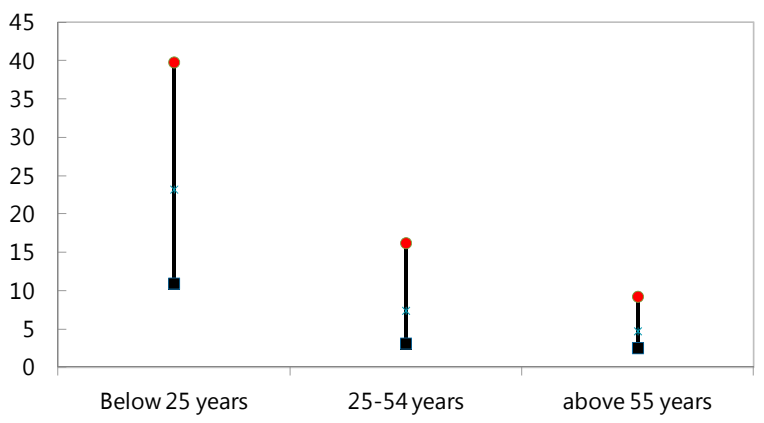

Sources: Eurostat; and ONEm.
Standard Deviation in Regional Unemployment Rates, 2010 (NUTS2, percent)

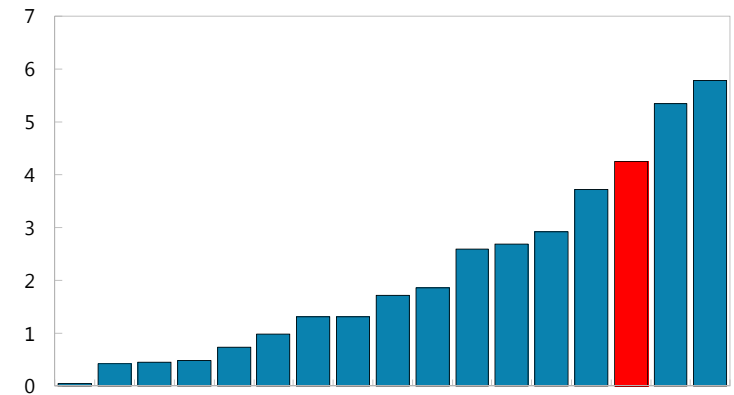

EA DK NO IE NL SE AT CH UK GR DE PT FI IT BE ES FR Source: Eurostat.

\begin{tabular}{lr}
\hline \multicolumn{2}{c}{ Convergence in unemployment rates 1/ } \\
2000-2010 \\
\hline Austria & 0 \\
Belgium & 0 \\
Portugal & 0 \\
Germany & $-0.0686^{* * *}$ \\
France & $-0.0687^{* *}$ \\
Italy & $-0.0928^{* * *}$ \\
UK & $-0.102^{* * *}$ \\
Spain & $-0.157^{* * *}$ \\
Sweden & $-0.355^{* * *}$ \\
Netherlands & $-0.409^{* * *}$ \\
\hline
\end{tabular}

1 / Coefficient estimates of the change in unemployment rates on lagged unemployment rates. A negative coefficient indicates convergence in unemployment rates. A zero coefficient indicates an estimate insignificantly different from zero at the 5 percent significance level.
6. In contrast, the dispersion of labor force participation rates is broadly in line with that in $\mathbf{E U}$ peers. Low activity rates are a country-wide phenomenon. The dispersion of labor force participation rates across provinces is relatively modest and in line with other countries of similar population size or Germany.
Regional Labor Force, 2010

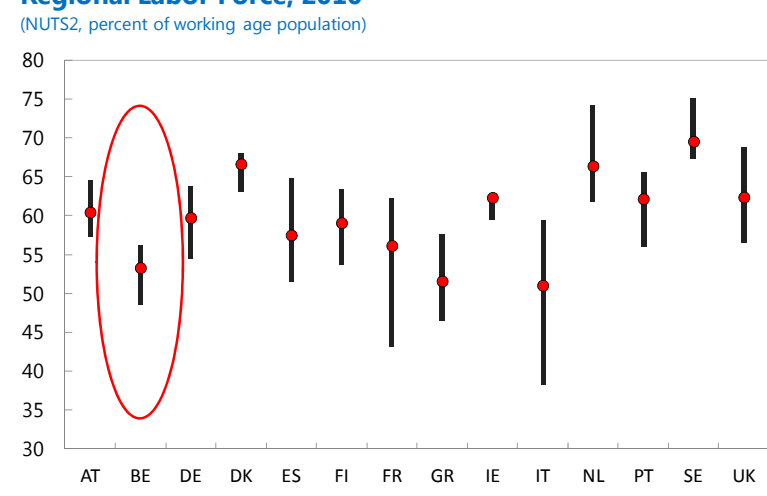

Source: Eurostat. 
7. Disparities in regional labor market outcomes may reflect structural differences that are amplified by labor market policies. Unemployment benefits, which are moderate by EU standards, are determined at the national level, but activation policies - and in this context, some of the monitoring efforts - are implemented at the regional level. Regional agencies refer job seekers who violate job search requirements to the national agency that imposes sanctions. For older workers, the level of pension benefits is similarly moderate by EU standards, but various early-retirement schemes encourage labor market dropout well before the official

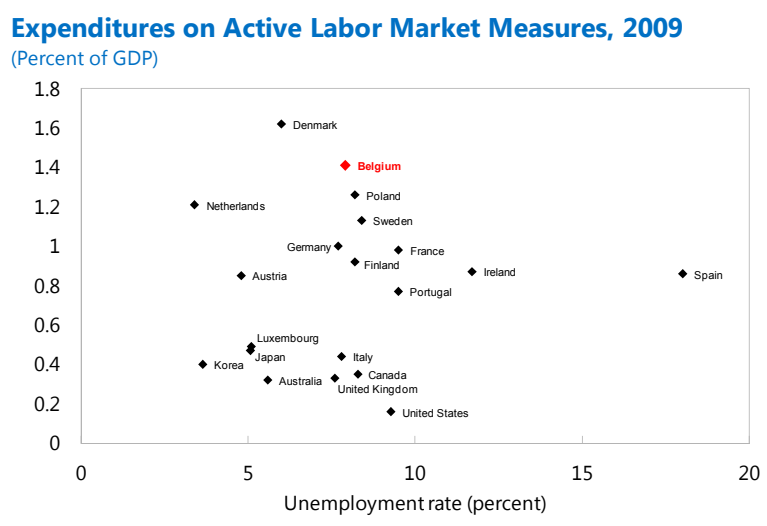

Sources: Eurostat; and OECD. retirement age of 65 years. These are not necessarily reflected in unemployment rates but reduce the share of employed in the working age population. Active labor market policies, including job search assistance, training, direct job creation, and employment support, are widely used and more costly than in other countries with similar unemployment rates.

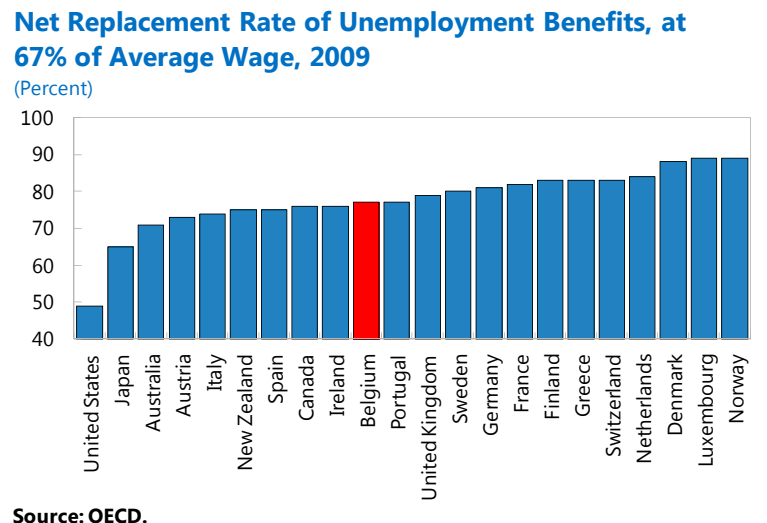

Source: OECD.

Note: For single-earner family with two-children at 67 percent of average wage.

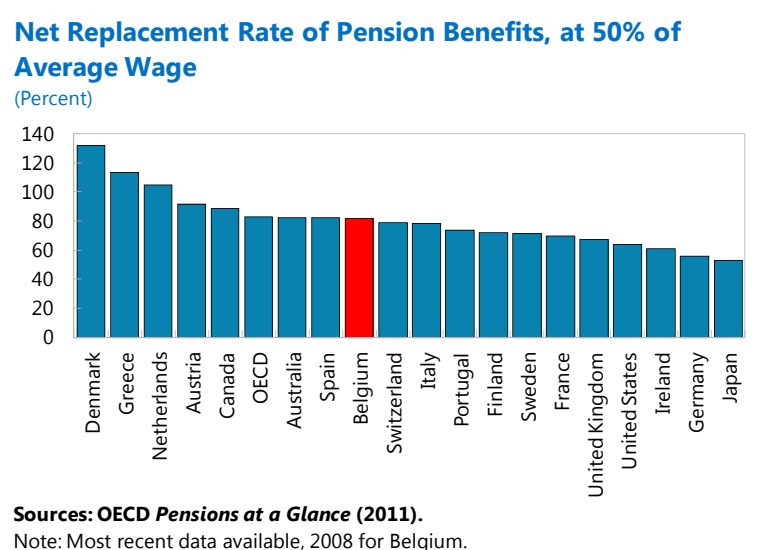

Sources: OECD Pensions at a Glance (2011). Note: Most recent data available, 2008 for Belgium

\section{B. Unemployment Benefits}

\section{Unemployment benefits are overall moderate by euro area standards but open-}

ended. With a net replacement rate of 60 percent for the average worker, they are initially lower than in other OECD countries, but in contrast to other OECD economies decline only marginally over time. In principle, unemployment benefits are 60 percent of the last salary up to a cap for one year. After the first year, the benefit drops to 55 percent of the last salary thereafter for single workers. For workers with a family, the benefit level is maintained even after the first year in the absence of other family income. If additional family income is available, unemployment benefits are reduced to 40 percent of the last salary but no lower than a lump sum of $€ 474.50$ per month. Workers above the age of 50 years have been eligible 
for higher benefits and benefits for specific family situations can be significantly higher. ${ }^{4}$ Unemployment benefits were paid indefinitely and not means-tested.

9. An important element of the reform agenda agreed in December 2011 was to make unemployment benefits more degressive over the duration of unemployment. The net replacement rate of benefits for the initial three months of unemployment is raised to 65 percent of the last wage, but will then drop back to the current level of 60 percent for the following nine months and is further reduced for all household types in several steps to a lump sum which is only little above the social assistance level. This lump sum is reached at the latest after four years of unemployment but much earlier for those unemployed with short working careers. Hence, the 5 percent increase in the net replacement rate of unemployment benefits during the first three months of employment will be matched by a reduction in benefits by the time the unemployment spells extends into 1/1/4-2 years (depending on working career length) and further thereafter. Unemployed above 55 years (previously 50 years) will remain eligible for higher unemployment benefits.

\section{Eligibility requirements for unemployment benefits have been lenient for some} groups. In principle, eligibility for unemployment benefits is conditional on active search efforts and availability for a suitable job. A suitable job is defined — during the first six months of job search - as a similar job to the pre-unemployment one within a radius of $25 \mathrm{~km}$ or a total travel time not exceeding four hours a day. Compliance with these eligibility requirements is verified by the regional public employment services from the start of the unemployment spell and by the benefit-providing federal authorities only after 18 months of unemployment and then at 12 months intervals (although regions monitor compliance more frequently). The reform agenda of December 2011 tightens eligibility criteria: A suitable job is redefined to include a perimeter of 60 kilometers and the frequency of federal monitoring of compliance with eligibility criteria will be doubled.

11. The strength of regional monitoring depends on resources allocated towards the task. For example, in Brussels one coach is responsible for 170 unemployed, in Wallonia for 140 unemployed, and in Flanders for 70 unemployed. For workers over the age of 50, eligibility requirements for unemployment benefits are not enforced by the federal authorities. This likely contributes to high unemployment among older workers. For Australia (Borland and Tseng, 2007) and the U.S. (Klepinger, Johnson, and Joesch, 2002), stricter job search requirements have been found to reduce the duration of unemployment spells.

\section{Unemployment benefits are also extended under several special schemes:}

\footnotetext{
${ }^{4}$ OECD (2011) estimated that for a worker with a family and an income one-third below the average wage the replacement rate is 86 percent.
} 
- Various career-break benefits exist. Those benefits are below unemployment benefits and are available for workers who take full-time career breaks for five years and/or reduce their working time for five years. No time limitation exists for workers above 50. Career breaks count fully towards pension entitlement. In the third quarter of 2011, about 270,000 workers received career-break benefits. The reforms agreed in December 2011 raise the minimum qualifying age for unlimited career breaks and part-time employment with benefits to 55 years, with some exceptions (e.g. long careers in physically demanding jobs) where the minimum age remains 50 years. In total, career breaks before the age of 55 are limited in the private sector to a maximum of four years. In addition, career breaks will only partially count towards pension benefits.

- $\quad$ Under the temporary unemployment program, the employer reduces temporarily working hours to accommodate reduced operations. Workers are compensated with partial unemployment benefits. These arrangements typically involve employer topup payments, so that the net income loss of workers is limited. The program was originally only available to blue-collar worker but was extended as one of the 2009 crisis measures to white-collar workers. The scheme has been widely used. In the first quarter of 2010, more than 256,000 workers received temporary unemployment benefits. This number had fallen below 116,000 workers by the third quarter of 2011 .

- $\quad$ Following a waiting period of nine months, young school leavers are entitled to unemployment benefits (called "waiting allowances"), although at less than full levels, without ever having contributed to the system. In the third quarter of 2011, about 110,000 unemployed received such waiting allowances. As part of the reform agreed in December 2011, the waiting period is extended to 12 months, waiting allowances are limited to 36 months, and young unemployed will be subject to more stringent monitoring of job search efforts.

- Involuntary part-time workers registered as job seekers for a full-time job can register for unemployment benefits. The total income from benefits and part-time employment can reach the income from a full-time job. Nearly 50,000 part-time workers were registered under the program in the third quarter of 2011. 


\section{Box III.1. The Administration of Unemployment Benefits}

Revenue collection and budget management responsibilities are centralized in the National Social Security Office (RSZ-ONSS). The responsibility for unemployment benefit delivery lies with the national unemployment fund (RVA-ONEM). For most people, local trade union offices act as paying agents for RVA-ONEM. RVA-ONEM assesses eligibility for benefits and imposition of sanctions, also upon referral from regional agencies. Participation in activation and job placement programs, is determined by regional public employment services. There are four regional employment services: Actiris in Brussels, the Flemish Employment and Vocational Training Agency in Flanders (VDAB), Forem in Wallonia, and Arbeitsamt for the German-speaking Community. Private employment agencies are also active, especially in Flanders. Actiris and the VDAB have a cooperation agreement to place unemployed from Brussels in Flanders, if they cannot find a job in Brussels. Although the national rules are uniform, implementation has differed in practice. For example, in 2007, Wallonia and Brussels imposed half as many sanctions (2.51 and 2.02 sanctions per hundred unoccupied job seekers, respectively) as Flanders (6.92 sanctions per hundred unoccupied job seekers). However, this has gradually changed and the relative ranking was reversed in 2010.

\section{Pension System}

\section{Aging costs are expected to rise by} $51 / 2$ percent of GDP over the course of the next five decades to about 31 percent of GDP. The High Council of Finance (2011) estimates that three quarters of this increase will be due to rising pension cost. The cost in percent of GDP of the public pension scheme for private and public sector employees will increase by almost half each. IMF (2011) suggests that this increase is about $1 \frac{1}{4}$ percentage point of GDP above the eurozone average.

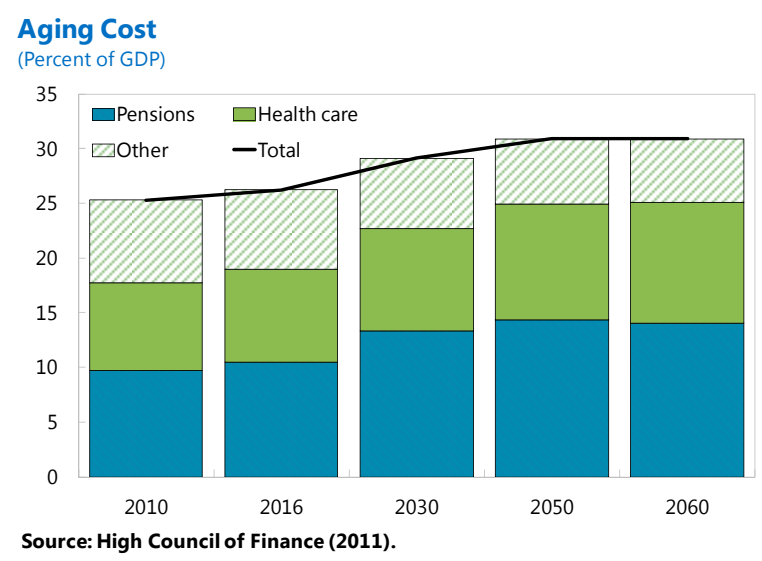

\section{Pillar I pensions are the predominant part of the Belgian pension system. The} public pension system for private employees differs from that for self-employed and public workers (that for public employees typically being more generous than that for private employees). ${ }^{5}$ In 2003, the Vandenbroucke Law promoted sectoral pension plans determined

\footnotetext{
${ }^{5}$ Public sector pension schemes differ for civil servants, contractual employees, and public enterprises, with some differences also between levels of government. For civil servants at the federal, regional, and municipal levels, pension benefits are calculated on the basis of the past five years of service and are indexed to the wage scale which has historically increased by more than in the private sector (OECD, 2011). The retirement age of 65 is mandatory and several schemes of early retirement, invalidity benefits and waivers exist. Neither
} 
by collective labor agreements, which differ between economic sectors and are administered by the social partners. In 2006, about 51 percent of the active population was covered by such sectoral agreements. Agreements typically are defined contributions (Trampusch at al., 2010). Finally, voluntary private pension insurance is available. For an average wage earner, such voluntary pension may add net replacement rates of 20 percent (OECD 2011).

\section{Five types of benefits are available to private sector employees above the age of}

50 (55 from 2012): unemployment benefits at lenient conditions, the pre-pension system (unemployment benefits with an employer top-up), career-break benefits, the early retirement system, and the standard pension system from the age of 65 . For workers above the age of 55 , expenditures on unemployment, pre-pension, and career-break benefits accounted for $1 \frac{1}{4}$ percent of GDP while pension payments amounted to $5 \frac{1}{2}$ percent of GDP in $2010 .^{6}$

- $\quad$ From the age of 50, workers on standard unemployment benefits do not have to search actively for work. The reform agenda agreed in December 2011 stipulates that this threshold age be raised to 55 years from 2013 and 58 years from 2016. Pension entitlements are accumulated at the last salary except when unemployment benefits are at the minimum lump sum. Workers often receive employer top-up payments and after one year of unemployment a supplement to their normal unemployment benefits.

- From the age of 50, workers who lose their job due to collective dismissals, restructuring or company losses, are entitled to "pre-pensions". From the age of 58 in most industries, "pre-pensions" are open to workers dismissed for any reason. Prepensions are unemployment benefits topped up by employers and with no obligation for job search. Almost one quarter of workers on unemployment benefits above the age of 50 are in the pre-pension scheme. Pension rights are accumulated throughout the period of pre-pension at the last full salary. The reforms agreed in December 2011 raise the minimum age for pre-pensions due to collective dismissal and restructuring to 55 years from 2013. In other cases, the current minimum age of 58 years is raised to 60 (from 2012 for new collective agreements, from 2015 for existing collective agreements). From 2013, recipients of pre-pension benefits below the age of 60 years would be required to search new jobs to qualify. The years below the age of 60 on pre-pensions will no longer count fully towards the career length applied toward pension benefits. To avoid companies selectively dismissing older workers, collective dismissals must reflect the age structure of the firm to qualify for pre-pension benefits. ${ }^{7}$

employers nor employees pay social security contributions for pensions for federal, regional, and municipal civil servants.

\footnotetext{
${ }^{6}$ Workers on career-break or time-credit benefits, with top up payments by employers are similar to prepensioners.

${ }^{7}$ A part-time pre-pension system that was available to employees working part-time will no longer be available from 2012.
} 
- $\quad$ Career breaks benefits have been available for workers above the age of 50 for an unlimited period, while they were limited to five year for younger workers. The reforms agreed in December 2011 increased the minimum age for an unlimited duration of career break benefits to 55 years. In some cases, the minimum age remains 50 years (e.g. long careers in physically demanding jobs).

- $\quad$ Early retirement pension benefits make the standard pension scheme available to workers aged 60 or above with a full career of 35 years. Benefit levels are adjusted for shorter career lengths below 45 years by $2 \frac{1 / 4}{4}$ percent per annum-well below the actuarially neutral rate of 5-6 percent per annum. A small pension supplement of $€ 2$ per day worked is provided for those working above the age of 61 . No supplementary pension rights are accumulated during the period of early retirement. Under the reforms agreed in December 2011, the minimum qualifying age for early retirement would be raised in six-month steps to 62 years and the minimum career would be extended in annual steps to 40 years by 2016 .

- $\quad$ From the age of 65, workers are eligible for pension benefits. Full benefits accrue for those above 65 years with a full career of 45 years. Benefits are reduced by $2 \frac{1}{4}$ percent per year for shorter careers - again, well below the actuarially neutral rate of 5-6 percent. For the private sector, pension benefits are 60 percent of the average wage over the whole career. In the public sector, pension benefits are based on the average salary of the last five years. Under the reforms agreed in December 2011, pensions for civil servants under the age of 50 will be based on the average wage of the last ten years from 2012. Pension (like unemployment benefits) are automatically adjusted by a subindex of the consumer price index (the "health index"). This contrasts with Germany (where inflation indexation is automatically corrected for the dependency ratio and growth in contributions) and France (where the indexation is regularly renegotiated).

\section{The standard pension benefit level is broadly in line with EU standards, but the} various early retirement and pre-pension schemes have higher replacement rates. The net replacement rate of the standard pension scheme is about 82 percent for low-wage workers (compared with an EU27 average of 82 percent) and 52 percent for high-wage workers. Since pre-pension schemes include top-up payments by employers, the net replacement rate of labor market exits for older workers before the official retirement age can be significantly higher and creates increased pension rights under the standard pension scheme.

\section{As a result of incentives to retire early,} the effective retirement age was 59 years in 2009. With Austria, Belgium has the widest gap between the official and the effective retirement age among OECD countries. Common use of early-retirement and prepension schemes partly reflects relatively strict

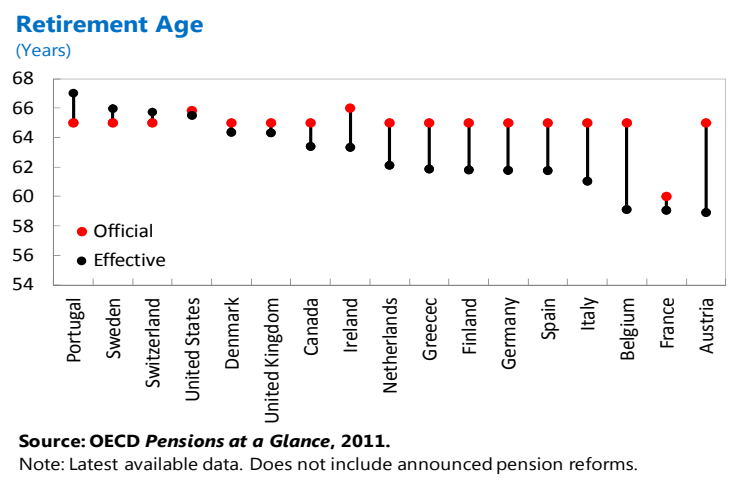


employment protection. This encourages employers to substitute outright worker dismissal with placement into benefit programs such as pre-pensions, career breaks and part-time work, or early retirement. In 2008, according to the OECD's employment protection index, Belgium's employment protection in cases of mass redundancies was the second most rigid after Italy's in the whole sample of OECD countries included in the ranking. For normal redundancies, Belgium ranked third among its Western European peers, after France, Greece, and Luxembourg.

\section{Access to early pension and} quasi-pension benefits is fairly uniform across the country. Compared with unemployment benefits, there is little dispersion in the share of the over-55 year-olds who receive some form of nonpension old-age support. While regions differ in the particular instrument of granting quasi-pensions, in aggregate they provide them to similar shares of the older working age population.

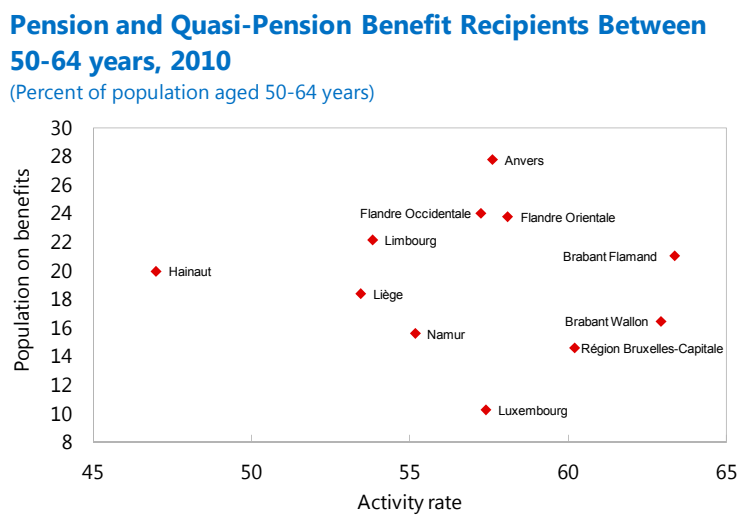

Sources: ONEm; Eurostat; and IMF staff estimates.

\section{Active Labor Market Policies}

\section{Belgium's expenditures on} active labor market policies are the second highest in the OECD (1.4 percent of GDP in 2009). Active labor market measures include job search assistance but also training, direct job creation, fiscal incentives for recruitment and employment maintenance, and fiscally supported employment schemes. Startup incentives for business creation are less than in other OECD countries.

\section{In Belgium, subsidized} employment and employment incentives account for the bulk of expenditures on active labor market measures. More than eighty percent of expenditures on active labor market measures are due to employment

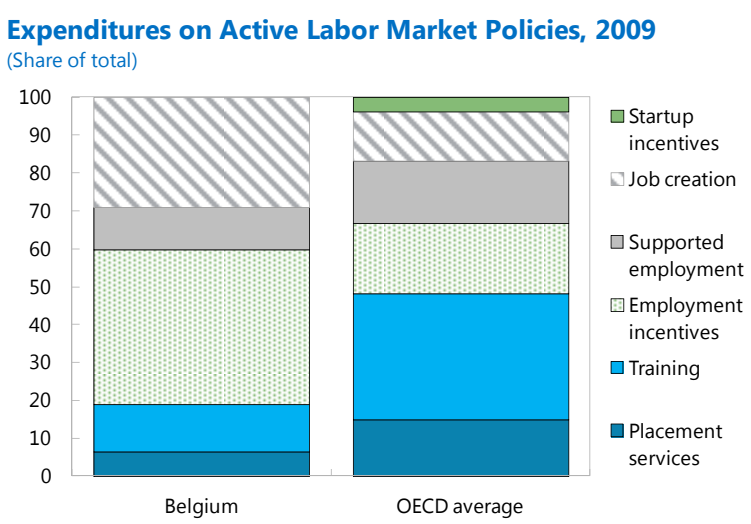

Source: OECD.

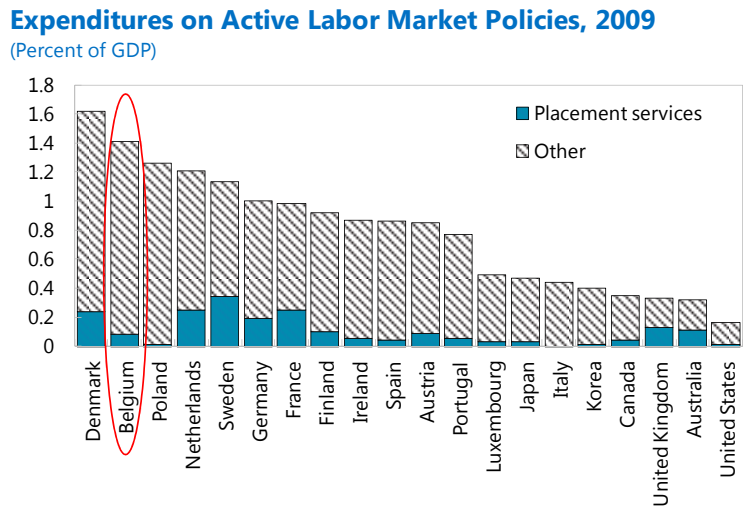

Source: OECD. 
subsidies in various forms. ${ }^{8}$ Especially Brussels employs these programs. Job search assistance accounted for only 6 percent of total expenditures on active labor market measures. This is less than half of the OECD average (14 percent). OECD (2007) describes how other countries have increasingly focused their expenditures on job search assistance, with participation in subsidized employment programs only after job search fails for an extended period. This is in line with a review of evaluation studies that finds particularly strong effects from job assistance and sanctions (Kluve, 2006).

\section{E. Impediments and Incentives for Mobility}

\section{Labor market mobility in general is limited in Belgium.}

- $\quad$ At a regional level, limited labor market mobility is often attributed to insufficient language skills.

- $\quad$ At the sectoral level, Vandenbrande (2000) documents the low mobility rates in and out of most sectors in Belgium compared with Sweden, Finland, and Norway. It is possible that the predominance of industry-financed training (rather than public vocational training) discourages worker training that is portable across industries.

22. The centralized wage setting mechanism compresses wage differentials and thus dulls incentives for labor market mobility. Biannual wage negotiations for the private sector start with a national agreement that sets an upper limit to wage increases composed of two elements, expected inflation for the next two years and a supplementary margin. This margin serves as a reference point for all sectors on top of the automatic price indexation. ${ }^{9}$ The result is a relatively homogeneous wage Hourly Wages, Regional Averages, 2004 structure across sectors and regions which does not adjust flexibly to local and sectoral labor market conditions. Davies and Hallet (2001) highlight the lack of regional wage differentials as one of the key reasons for persistent regional unemployment differentials in EU countries. In addition, the seniority premium in Belgium is among the highest in Western European countries, after Luxembourg, Italy, and Greece (Mastribuoni

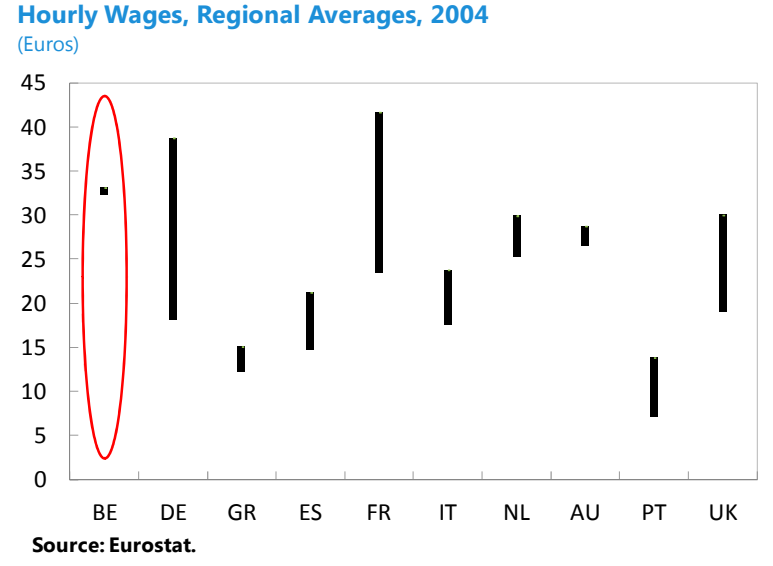

\footnotetext{
${ }^{8}$ Employment incentives include the Plan Win-Win introduced during the 2008/09 crisis. Under the Plan WinWin, an employer receives $€ 500-1100$ per month for hiring a young, old, or long-term unemployed worker for a limited period of time.

${ }^{9}$ Automatic price indexation is established by law for the public sector only but de facto often applied in the private sector. The base index for the automatic indexation has occasionally been redefined to remove temporary shocks. Currently, the indexation is based on the "health index" which excludes fuel prices and some items with heavy excise taxes from the CPI.
} 
and Taddei, 2011), thus making it difficult for unemployed older workers to find new employment.

\section{F. The Importance of Labor Market Policies}

\section{A key question in any analysis of social benefits is to what extent the business cycle causes unemployment and low labor market participation and to what extent} social benefits do. The business cycle is a national or EU-wide phenomenon. In a perfectly flexible labor market, workers from regions and industries in a slump would relocate to rising regions and industries. Social benefits and regulatory rigidities may hinder this relocation.

\section{In this section, the effect of the interaction of social benefits with regional} population structures is analyzed econometrically using a dataset of subnational labor markets outcomes from Eurostat's regional database. By focusing on subnational labor market outcomes, the interaction of social benefits with regional population characteristics, notably its age structure, can be distilled. The regressions are used as a tool to identify statistical patterns rather than a comprehensive analysis of the determinants of regional unemployment rates. In this spirit, they control for an EU-wide business cycle by including time dummies and for country characteristics beyond those of immediate interest here or those unavailable for data reasons by including country dummies. ${ }^{10}$ (While this precludes the separate inclusion of country-level variables, it is a comprehensive control for country-level omitted variables.) Regional labor market data at the NUTS3 level — the municipal level, in the case of Belgium - to 2009 is used. Labor market outcomes such as unemployment or employment are stocks and, hence, highly persistent. The autocorrelation caused by this persistence would bias the estimates. To mitigate the persistence somewhat, annual averages are created over the periods 2000-2003, 2004-2007, and 2008-2009. ${ }^{11}$

\section{The variable of interest here is the municipal employment rate- the share of} employed in the working age population. This variable will inter alia be driven by disincentives inherent in the unemployment system to both drop out of the labor market entirely and to remain unemployed. In the literature on unemployment differentials in the U.S. and Canada, the focus is on regional differences in social security systems (for an overview see Elhorst, 2000). In European countries, in contrast, social security benefits are

\footnotetext{
${ }^{10}$ Lopez-Bazo, Barrio and Artis (2002) also control for region-specific unit labor cost, shares of agriculture, and human capital. The full list of covariates is not included here. The most recent labor force survey available from Eurostat (2008) only provides country-wide wage cost data, hence would be captured by the country dummy. Regional data on the share of agriculture in employment or value added are also not available. Regional educational attainment, while available, was insignificant when included in the regression below.

${ }^{11}$ The regression results in Table III.1 are based on NUTS3 data. At the time of writing, the NUTS2 data-at the provincial level for Belgium - was available until 2010 while NUTS3 data was available only until 2009. If NUTS2 data were used, the results for are similar except that the coefficient on the share of below-25 year olds would lose significance in Column II of Table III.1. For the regression in Column III of Table 1 there would be insufficient degrees of freedom to estimate the coefficients precisely.
} 
typically set and applied nation-wide. Of interest here is therefore the interaction between the population structure in a region and the generosity of the country-wide unemployment system - both for young and for old workers. Young workers tend to have below-average wages. Hence, for young workers, the focus here is on the interaction between the net replacement rate at wages one-third below the average wage and the share of the provincial population below the age of 25 . Older workers tend to have average or above-average wages. Hence, for workers from the age of 55 onwards (i.e. those still well below the official retirement age), the regressions focus on the interaction of their share in the provincial population with the net replacement rate of unemployment benefits for workers at average wages. ${ }^{12}$ In sum, the following regression is run:

$$
\begin{aligned}
e r_{j i t}= & \text { share }_{j i t}^{\text {young }}+\text { share }_{j i t}^{\text {young }} \times \text { benefit }_{i t}^{\text {low wage }} \\
& + \text { share }_{j i t}^{\text {old }}+\text { share }_{j i t}^{\text {old }} \times \text { benefit }_{i t}^{\text {average wage }} \\
& + \text { country dummy }_{i}+\text { time dummy }_{t}+\varepsilon_{j i t}
\end{aligned}
$$

\section{The results suggest that, in this sample, more generous unemployment benefit} systems were associated with a stronger correlation between the population age structure and the employment rate. Column I in Table III.1 shows the correlation between the age structure and municipal employment rates: a greater share of people below 25 years and above 55 years was associated with a lower employment rate. Column II introduces the two interaction terms: the share of below-25 year olds interacted with the net replacement rate for worker with below-average incomes and the share of above-55 year olds interacted with the net replacement rate for workers with average wages. The results in Column II suggest that the negative correlations shown in Column I were driven by the benefit system. By itself, a greater share of below-25 year olds was now associated with greater employment rates while that of workers above 55 years no longer had any impact. This is in line with earlier evidence (for a summary, see Box 3 of IMF, 2011). The interaction terms with benefit levels are significantly negative: the higher net replacement rates of unemployment benefits, the greater the drag of a large share of workers at either end of the working age population on employment rates. Column III raises the bar higher: it also includes country-time dummies to control for country-specific business cycles. Again, controlling for the interaction terms, a greater share of below-25 year olds was associated with a greater employment rate and the share of above-55 year olds had no significant impact. Where the unemployment benefit system was generous, however, it dampened the positive link between employment and the share of people below 25 years (albeit with marginal significance) while it turned a larger population of above-55 year olds into a drag on employment rates. Finally, the regressions in Columns I-III fall short from other studies in the literature that control for other provinciallevel characteristics, such as industry structure and unit labor cost (Lopez-Bazo, Barrio and

\footnotetext{
${ }^{12}$ Ideally, the net replacement rate for pension benefits would be included in the regression. However, to date the dataset only includes pension data from the 2011 vintage of the OECD's Pensions At A Glance. Hence, the panel dimension is lost; in the cross-section alone, coefficient estimates on pension benefits are insignificant.
} 
Artis, 2002). Comparable municipal-level data are not available for the whole period in this sample. However, they can be controlled for by using a provincial fixed-effects regression. All provincial characteristics, including the age structure, would be captured in the provincial fixed effects. Results are shown in Column IV of Table III.1. Again and as expected, the interaction between unemployment benefits and the share of the youngest or oldest members of the working age population was significantly negative.

Table III.1. Panel OLS Regression. Dependent Variable: Employment Rate (percent)

\begin{tabular}{|c|c|c|c|c|}
\hline VARIABLES & 1 & II & $\begin{array}{l}\text { III Country-time } \\
\text { dummies }\end{array}$ & $\begin{array}{l}\text { IV Region fixed } \\
\text { effects }\end{array}$ \\
\hline $\begin{array}{l}\text { Share of below- } 25 \text { year olds } \\
\text { in population }\end{array}$ & $\begin{array}{l}-0.496^{\star * *} \\
{[0.00]}\end{array}$ & $\begin{array}{l}0.600^{\star * *} \\
{[0.01]}\end{array}$ & $\begin{array}{l}3.007^{\star * *} \\
{[0.00]}\end{array}$ & \\
\hline $\begin{array}{l}\text { Share of above- } 55 \text { year olds } \\
\text { in population }\end{array}$ & $\begin{array}{l}-0.251^{* *} \\
{[0.04]}\end{array}$ & $\begin{array}{l}0.153 \\
{[0.60]}\end{array}$ & $\begin{array}{l}0.884 \\
{[0.24]}\end{array}$ & \\
\hline $\begin{array}{l}\text { Share of below- } 25 \text { year olds } \\
\left.{ }^{*} \text { net replacement rate ( } 67 \% \text { of average wage }\right)\end{array}$ & & $\begin{array}{c}-0.564^{*} \\
{[0.06]}\end{array}$ & $\begin{array}{c}-1.355^{\S} \\
{[0.15]}\end{array}$ & $\begin{array}{c}-0.436^{* * *} \\
{[0.00]}\end{array}$ \\
\hline $\begin{array}{l}\text { Share of above- } 55 \text { year olds } \\
\text { *net replacement rate (average wage) }\end{array}$ & & $\begin{array}{l}-1.311^{* * *} \\
{[0.00]}\end{array}$ & $\begin{array}{l}-4.046^{* * *} \\
{[0.00]}\end{array}$ & $\begin{array}{l}-0.518^{* * *} \\
{[0.01]}\end{array}$ \\
\hline Constant & $\begin{array}{c}68.69^{* * *} \\
{[0.00]}\end{array}$ & $\begin{array}{c}69.76^{\star * *} \\
{[0.00]}\end{array}$ & $\begin{array}{c}67.85^{\star * *} \\
{[0.00]}\end{array}$ & $\begin{array}{c}64.54^{* * *} \\
{[0.00]}\end{array}$ \\
\hline Observations & 404 & 404 & 404 & 404 \\
\hline Number of provinces & 202 & 202 & 202 & 202 \\
\hline R-squared & 0.675 & 0.676 & 0.674 & 0.098 \\
\hline
\end{tabular}

Note: Robust pvalues in brackets.

${ }^{* * *} p<0.01,{ }^{* *} p<0.05,{ }^{*} p<0.1,{ }^{\S} p<0.15$.

Country and time dummies are not reported here.

\section{These statistical correlations suggest that, until the recent reforms, the Belgian} unemployment benefit system may have been sufficiently generous to turn a high share of below-25 year olds and above-55 year olds into a drag on employment rates.

Consider, for example, the overall effect of a 1 percentage point increase in the share of below-25 year olds. The overall effect is composed of both the level effect (estimated by the coefficient 0.60 in Column II of Table III.1) and the interaction with the net replacement rate of unemployment benefits for below-average wage earners that prevailed in Belgium on average during 2008-10 (estimated with a coefficient of -0.564 in Column II of Table III.1). Hence, the overall effect of a 1 percentage point increase in the share of below- 25 year olds - shown in the coefficient line at its intersection with the vertical line in the left figure below - was to reduce the employment rate by $1 / 2$ percentage point. Similarly, given the Belgian unemployment benefit system, the overall effect of a 1 percentage point increase in the share of above-55 year olds was to reduce the employment rate by $1 / 4$ percentage point. 

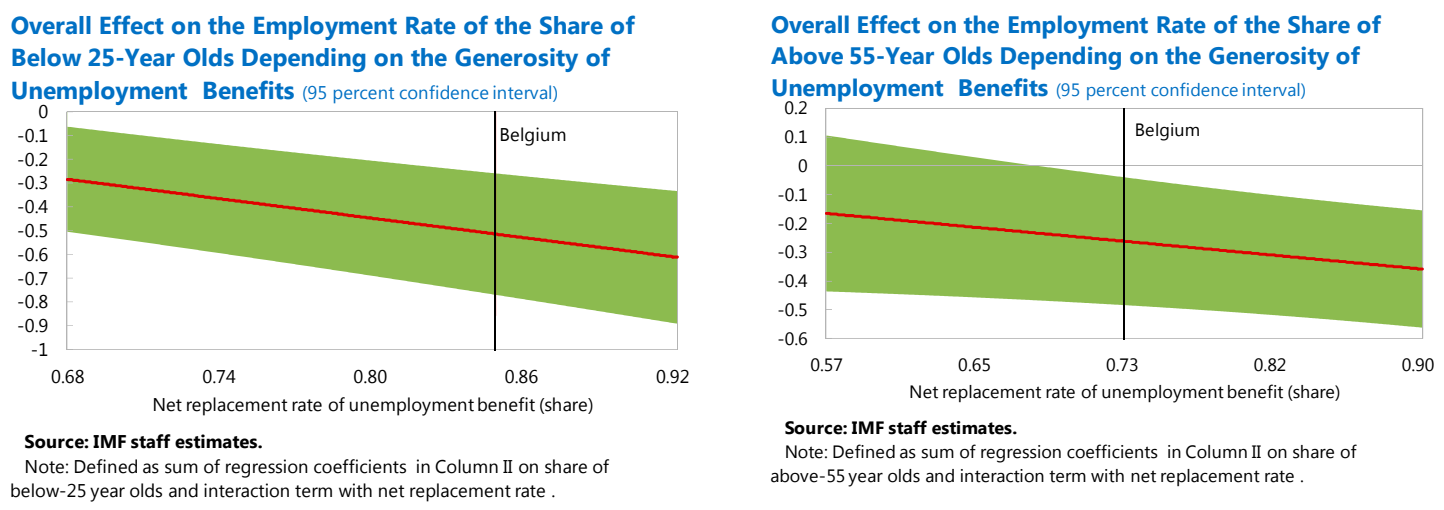

28. What might be expected if the net replacement rates of Belgian unemployment benefits were reduced by, say, 5 percentage points? Compared to the pre- 2012 system, a 5 percentage point cut is approximately what an unemployed can expect after $1 \frac{1}{2}-2$ years of unemployment. Based on the coefficient estimates from Column II of Table III.1 and the age structure of Belgium's regions, the potential impact on employment rates can be derived. A 5 percentage point cut in the net replacement rate for all unemployment benefits might raise the employment rate by 2-3 percentage point. This is not insignificant in view of the government's target to raise the employment rate by 5 percentage points.

\section{G. Further Reform Needs}

29. Raising employment is key to strengthening potential growth and ensuring fiscal sustainability. In particular, the combined unemployment and pension benefit systems provide incentives for labor market exit well before the official retirement age of 65 years. Pre-pension and early retirement benefits and lenient provisions for benefits during career break and unemployment spells encourage workers above 50 years to reduce their labor market participation. An illustrative regression suggests that the current unemployment benefits distort the impact of the population age structure and reduces regional employment rates in Belgium.

\section{The labor market and pension reforms agreed in December 2011 are steps} towards raising employment (Appendix Table A.1). They span the unemployment benefit system, including various paths to early labor market exit, as well as pension reform. In the unemployment benefit system, search requirements will be enforced more strictly, the benefit duration will be reduced for the young, benefit levels will be made more degressive over the duration of unemployment. In the unemployment benefit system for older workers, higher benefits will only begin at the age of 55 years, the pre-pension system will become less accessible because of tightened age and career conditions and will become less attractive for employers with higher taxes on employer top-up payments. Pre-pension benefits will become altogether inaccessible before the age of 55 years in cases of dismissal in restructuring and loss-making companies. In the pension system, minimum ages for qualifying for early retirement pension benefits will be raised and the benefit levels reduced for participation in 
career break and pre-pension schemes. Additional measures will be phased in more slowly. In 2013, these include working time calculations based on annual wages and enforcement of job search requirements for workers from the age of 55. In the pension system, the minimum age for early retirement benefits will be gradually increased to 62 years by 2016 . Key to the success of these reforms will be their consistent implementation, including monitoring and removing if needed loopholes, e.g., in the system of sickness and disability benefits.

31. Nevertheless, further reforms may be needed to increase the employment rate by 5 percentage points as articulated in the government program. These could include some of the following specific measures:

- Unemployment benefits: Unemployment benefits distort labor market incentives to reduce employment rates. Further reforms of benefits and eligibility requirements for workers below 25 years (including in waiting allowances) and above 55 yearssupplemented by enhanced search support - could help increase the employment rate. The regression estimates in this note suggest that the government's emphasis on activating the youngest and oldest labor market participants is the right one.

- $\quad$ Pension and quasi-pension benefits: The combined unemployment and pension benefit systems provide incentives for labor market exit well before the official retirement age of 65 years. The recent reforms strengthen incentives to remain in the labor market beyond the age of 50 years but may be too modest to raise the effective retirement age well above 60 years. In addition, pension benefits could be made actuarially neutral at a discount rate of 5-6 percent.

- $\quad$ Search assistance: Employment agencies allocate a smaller share of their resources to job search support than their OECD peers. A reallocation towards job search assistance and training could help to better match job seekers and vacancies across regions and provinces.

- $\quad$ Wage setting mechanism: The wage setting mechanism produces exceptionally small regional and sectoral variation. Allowing greater wage flexibility across sectors and regions in the wage bargaining mechanism could help encourage labor market mobility. 


\section{References}

Klepinger, D.H., T.R. Johnson and J.M. Joesch (2002), "Effects of Unemployment Insurance Work-Search Requirements: The Maryland Experiment”, Industrial and Labor Relations Review, No. 56, pp. 3-22.

Kluve, J. (2006), “The Effectiveness of European Active Labour Market Policy”, IZA Discussion Paper, No. 2018, Bonn.

Borland, J. and Y.P. Tseng (2007), "Does a Minimum Job Search Requirement Reduce Time on Unemployment Payments? Evidence from the Jobseeker Diary in Australia”, Industrial and Labor Relations Review, Vol. 60, No. 3, April.

Davies Sara and Martin Hallet (2001), "Policy responses to regional unemployment: Lessons from Germany, Spain, and Italy,” European Economic-Economic Papers No. 161.

Elhorst, Paul, (2000), “The Mystery of Regional Unemployment Differentials: A Survey of Theoretical and Empirical Explanations," Journal of Economic Surveys, Vol. 17, Issue 5, pp. 709-748.

OECD (2007), “Activating the Unemployed: What Countries Do," in OECD Employment Outlook 2007, Paris: OECD, pp. 207-242.

OECD (2011), "Pensions at a Glance 2011: Retirement-Income Systems in OECD and G20 Countries," Paris: OECD.

Economic Survey Belgium (2011), OECD.

IMF, (2011), "The Challenge of Pension Reform in Advanced and Emerging Countries," IMF Board Paper (forthcoming).

Lopez-Bazo, Enrique, Tomas del Barrio, and Manuel Artis, (2002), "The regional distribution of Spanish unemployment: a spatial analysis," Papers in Regional Science, Vol. 81, No. 3, pp. 365-389.

Mastrobuoni, Giovanni and Taddei, Filippo, (2011), "Age Before Beauty? Productivity and Work vs. Seniority and Early Retirement” Netspar Discussion Paper No. 05/2011-062. Available at SSRN: http://ssrn.com/abstract=1889054.

Trampusch, Christine; Pierre Eichenberger; Micha de Roo; Robin, Bartlett Rissi; Isabelle Bieri; Isabelle; Laura Schmid; and Simon Steinlin (eds.) (2010), "Pension in Belgium," REBECA (Research on Social Benefits in Collective Agreements). Database, Part 2 'Social Benefits in Collective Agreements'. SNF-Project No. 100012-119898. Institute of Political Science, University of Berne. 
Vandenbrande, Tom (2000), "First exploration of the Belgian HRST data", OECD Focus Group Paper.

High Council of Finance (2011), “Comité d'Etude sur le Vieillissement," Annual Report.

Adema, Willem, (2006), "Social Assistance Policy Development and the Provision of a Decent Level of Income in Selected OECD Countries," OECD Social, Employment, and Migration Working Paper No. (2006)38. 


\section{Appendix Table A.1. Labor Market and Pension Reform Measures for 2012}

\begin{tabular}{|c|c|c|}
\hline & 2011 system & 2012 system \\
\hline \multicolumn{3}{|l|}{ Unemployment benefits } \\
\hline \multirow[t]{3}{*}{ Search requirements } & Suitable job is $<=25 \mathrm{~km}$ away & Suitable job is $<=60 \mathrm{~km}$ away \\
\hline & $\begin{array}{l}\text { Restrict definition to same kind of } \\
\text { job for } 6 \text { months }\end{array}$ & $\begin{array}{l}\text { Restrict definition to same kind of } \\
\text { job for } 3 \text { months (young } \\
\text { unemployed) and } 5 \text { months (other } \\
\text { unemployed) }\end{array}$ \\
\hline & $\begin{array}{l}\text { Monitor search efforts } 18-21 \\
\text { months after unemployment, with } \\
\text { 12-monthly follow-up }\end{array}$ & $\begin{array}{l}\text { Monitor search efforts } 9 \text { months } \\
\text { after unemployment, with 6- } \\
\text { monthly follow-up }\end{array}$ \\
\hline \multirow[t]{3}{*}{ Unemployment benefit levels } & $\begin{array}{l}\text { Initial unemployment benefits are } \\
60 \text { percent of last wage, falling to } \\
58 \text { percent of wage after } 1 \text { year }\end{array}$ & $\begin{array}{l}\text { Initial unemployment benefits are } \\
65 \text { percent of last wage for } 3 \\
\text { months, then } 60 \text { percent for the } \\
\text { following } 9 \text { months, then a } \\
\text { stepwise reduction over the } \\
\text { following } 3 \text { years to just above } \\
\text { the social assistance level }\end{array}$ \\
\hline & $\begin{array}{l}\text { Benefits are not adjusted for } \\
\text { career length }\end{array}$ & $\begin{array}{l}\text { Benefits are adjusted for career } \\
\text { length from the second year of } \\
\text { unemployment }\end{array}$ \\
\hline & $\begin{array}{l}\text { Higher unemployment benefits for } \\
\text { those above } 50\end{array}$ & $\begin{array}{l}\text { Higher unemployment benefits for } \\
\text { those above } 55\end{array}$ \\
\hline \multirow[t]{2}{*}{ Youth unemployment benefits } & $\begin{array}{l}\text { Available after } 9 \text { months of } \\
\text { unemployment }\end{array}$ & $\begin{array}{l}\text { Available after } 12 \text { months of } \\
\text { unemployment } \\
\text { Unemployment benefit thereafter } \\
\text { conditional on search effort to be } \\
\text { monitored at } 6 \text {-month intervals. }\end{array}$ \\
\hline & Unlimited & $\begin{array}{l}\text { Limited to three years (five years } \\
\text { for worker on the margin of the } \\
\text { labor market) for unemployed } \\
\text { living with family with other } \\
\text { income, or until the age of } 33 \text { in } \\
\text { other family situations }\end{array}$ \\
\hline Temporary unemployment & Without employer penalty & $\begin{array}{l}\text { Employers will have to pay a } \\
\text { penalty if a limited number of } \\
\text { working days is exceeded }\end{array}$ \\
\hline \multirow[t]{3}{*}{$\begin{array}{l}\text { Time-credit and career break } \\
\text { system }\end{array}$} & $\begin{array}{l}5 \text { year duration before the age of } \\
50\end{array}$ & $\begin{array}{l}1 \text { year duration }(2-5 \text { years if part- } \\
\text { time) before the age of } 55\end{array}$ \\
\hline & $\begin{array}{l}\text { Unlimited duration above the age } \\
\text { of } 50\end{array}$ & $\begin{array}{l}\text { Unlimited duration above the age } \\
\text { of } 55\end{array}$ \\
\hline & 72 month duration in public sector & 60 month duration in public sector \\
\hline
\end{tabular}




\section{Appendix Table A.1. Labor Market and Pension Reform Measures for 2012}

\section{(concluded)}

\begin{tabular}{|c|c|c|}
\hline & 2011 system & 2012 system \\
\hline \multicolumn{3}{|l|}{ Pension benefits } \\
\hline $\begin{array}{l}\text { Pre-pension benefits } \\
\text { (changed to "Unemployment }\end{array}$ & No job search requirement & $\begin{array}{l}\text { Job search requirement until the } \\
\text { age of } 55 \text { (in 2013) and } 58(2016)\end{array}$ \\
\hline \multirow[t]{4}{*}{ benefits with employer topup") } & Minimum age 58 & $\begin{array}{l}\text { Minimum age } 60 \text { for new } \\
\text { collective agreements ( } 2015 \text { for } \\
\text { existing agreements) }\end{array}$ \\
\hline & $\begin{array}{l}\text { Minimum career length for full } \\
\text { benefits } 38 \text { years for men, } \\
25 \text { years for women }\end{array}$ & $\begin{array}{l}\text { Minimum career length } 40 \text { years } \\
\text { for new collective agreements } \\
\text { ( } 2015 \text { for existing agreements) }\end{array}$ \\
\hline & $\begin{array}{l}\text { Pre-pension years count fully } \\
\text { towards the pension at the last } \\
\text { minimum wage }\end{array}$ & $\begin{array}{l}\text { Pre-pension years below the age } \\
\text { of } 60 \text { do not count towards } \\
\text { pension rights at last full wage }\end{array}$ \\
\hline & $\begin{array}{l}\text { Reduced social security } \\
\text { contributions on employer's top- } \\
\text { up payment }\end{array}$ & $\begin{array}{l}\text { Employer social security } \\
\text { contributions will be higher and } \\
\text { linked to age of worker entering } \\
\text { pre-pension }\end{array}$ \\
\hline Part-time pre-pension system & & No more new entries from 2012 \\
\hline $\begin{array}{l}\text { Time-credit with unlimited } \\
\text { duration }\end{array}$ & Minimum age 50 & $\begin{array}{l}\text { Minimum age } 55 \text { (with exceptions } \\
\text { for physically demanding jobs) }\end{array}$ \\
\hline \multirow[t]{4}{*}{$\begin{array}{l}\text { Pre-pension for collective } \\
\text { dismissal }\end{array}$} & Minimum age 50 & $\begin{array}{l}\text { Minimum age } 52 \text { for loss-making } \\
\text { companies (from 2012), raised by } \\
6 \text { months every year, } 55 \text { for } \\
\text { restructuring companies } \\
\text { (from 2013) }\end{array}$ \\
\hline & $\begin{array}{l}\text { Pre-pension years count fully } \\
\text { towards the pension at the last } \\
\text { minimum wage }\end{array}$ & $\begin{array}{l}\text { Pre-pension years below the age } \\
\text { of } 60 \text { do not count towards } \\
\text { pension rights at last full wage }\end{array}$ \\
\hline & $\begin{array}{l}\text { No restrictions on dismissed } \\
\text { workers' age structure in } \\
\text { collective dismissals }\end{array}$ & $\begin{array}{l}\text { Collective dismissals must reflect } \\
\text { the age structure of the firm }\end{array}$ \\
\hline & $\begin{array}{l}\text { Standard social security } \\
\text { contributions }\end{array}$ & $\begin{array}{l}\text { Employer social security } \\
\text { contributions will be linked to age } \\
\text { of worker entering pre-pension }\end{array}$ \\
\hline Unemployment benefits & $\begin{array}{l}\text { No job search requirement for } \\
\text { those above the age of } 50\end{array}$ & $\begin{array}{l}\text { Job search requirement until the } \\
\text { age of } 55 \text { (in 2013) }\end{array}$ \\
\hline Early retirement benefit & $\begin{array}{l}\text { Minimum age } 60 \text {, full career } \\
\text { length } 35 \text { years }\end{array}$ & $\begin{array}{l}\text { Minimum age increased by } 6 \\
\text { months every year to } 62 \text { by } 2016 \text {, } \\
\text { full career length increased by } 1 \\
\text { year every year to } 40 \text { years } \\
\text { by } 2016\end{array}$ \\
\hline Employer obligation & None & $\begin{array}{l}\text { Draw up a plan to retain older } \\
\text { workers }\end{array}$ \\
\hline Social security contributions & $\begin{array}{l}\text { Reduced for hiring of older long- } \\
\text { term unemployed }\end{array}$ & $\begin{array}{l}\text { Reduced for hiring of older } \\
\text { longterm unemployed and pre- } \\
\text { pensioners }\end{array}$ \\
\hline
\end{tabular}

Source: SPF Emploi, Travail, et Concertation Sociale, NBB. 